ORCID: 0000-0002-6918-2602

\author{
Mateusz Piąt kowski
}

Wydział Prawa i Administracji Uniwersytetu Łódzkiego

\title{
Bombardowania powietrzne w okresie II wojny światowej w świetle prawa międzynarodowego: problem ataku na Wieluń 1 września 1939 roku $^{1}$
}

\begin{abstract}
Air bombings committed during World War II are still the subject of lively political and historical discussions. The scale of damage done by the air force in this conflict raises questions about the importance of international law in force in armed conflicts, especially its role in reducing the atrocities of war and protecting those who do not participate in hostilities. This article is an attempt to answer the question about the scope of the legal regime to which the phenomenon of air bombing was subjected.

Symbolem okresu II wojny światowej są obrazy zniszczonego Wielunia, zrujnowanej Warszawy czy też płonącej Katedry Świętego Pawła

1 W systematyce międzynarodowego prawa humanitarnego stosuje się podział na prawo wojny lądowej, morskiej oraz powietrznej. Są to istniejące obok ogólnych zasad międzynarodowego prawa humanitarnego reżimy szczególne, uwzględniające różnice $\mathrm{w}$ charakterze operacji zbrojnych toczonych na lądzie, morzu oraz w powietrzu. W ramach tych reżimów, zwłaszcza do 1977 r., można wyróżnić odrębne zasady bombardowań (np. w kontekście wojny morskiej była to IX konwencja haska z 1907 r. o bombardowaniach morskich czy też przepisy Regulaminu haskiego z 1907 r. stanowiące o bombardowaniach lądowych). Po 1977 r., w związku z ujednoliceniem reżimu bombardowania celów na lądzie w ramach Protokołu dodatkowego I (Protokół dodatkowy do konwencji genewskich z 12 VIII 1949 r., dotyczący ochrony ofiar międzynarodowych konfliktów zbrojnych z 1977 r.), podział ten częściowo stracił na aktualności, ale wciąż Protokół dodatkowy I nie reguluje np. działań powietrze-morze, morze-morze, pozostawiając te zagadnienia ogólnym zasadom międzynarodowego prawa humanitarnego i normom zwyczajowym wojny morskiej i powietrznej.
\end{abstract}


$\mathrm{w}$ Londynie. Z drugiej strony $\mathrm{w}$ ramach konfliktu dopuszczono się szerokiej destrukcji wielu miast niemieckich oraz japońskich. Wszystkie te akty zostały dokonane za pomocą niszczycielskiej mocy lotnictwa bombowego, wykorzystującego ciężkie wielosilnikowe bombowce, zdolne do przenoszenia potężnego ładunku bomb. Najbardziej krwawy pojedynczy akt II wojny światowej - bombardowanie Tokio nocą 9/10 marca 1945 r. - unicestwił prawie 100 tys. istnień ludzkich. W erze wojny totalnej pojawiają się pytania co do roli prawa międzynarodowego, a w szczególności prawa obowiązującego w trakcie/czasie konfliktu zbrojnego (ius in bello) jako narzędzia ograniczenia zabijania, ranienia ludności cywilnej bądź niszczenia dóbr nieposiadających charakteru militarnego. ${ }^{2}$

W pierwszej kolejności należy zauważyć, że zgodnie ze stanowiskiem sędziego Maxa Hubera wyrażonym na gruncie sprawy wyspy Palmas, zdarzenia prawne winny być oceniane zgodnie z prawem obowiązującym w chwili ich powstania. ${ }^{3} \mathrm{~W}$ konsekwencji niedopuszczalne jest dokonywanie oceny przebiegu bombardowań powietrznych z czasów II wojny światowej z perspektywy aktualnie istniejącego obrazu normatywnego międzynarodowego prawa humanitarnego, zwłaszcza poprzez dokonywanie „wstecznego" stosowania przepisów przyjętych już po 1945 r. (protokołu dodatkowego I do konwencji genewskich o ochronie ofiar międzynarodowych konfliktów zbrojnych z 1977 r.). ${ }^{4}$ Dotyczy to $\mathrm{w}$ pierwszej kolejności zagadnienia związanego z tzw. doktryną celu wojskowego. ${ }^{5}$ Jest to wstępna trudność

2 Konwencja dotycząca praw i zwyczajów wojny lądowej (Dz. U. 1927, nr 21, poz. 161); Konwencja genewska o polepszeniu losu chorych i rannych w armjach czynnych, podpisana dnia 27 VII 1929 r. (Dz. U. 1932, nr 103, poz. 864); Protokół dotyczący zakazu używania na wojnie gazów duszących, trujących lub podobnych oraz środków bakteriologicznych (Dz. U. 1929, nr 28, poz. 278). Po przyjęciu konwencji genewskich z 1949 r. pojęcie wojny, z uwagi na jego subiektywny charakter, zostało zastąpione szerszym znaczeniowo pojęciem konfliktu zbrojnego (obejmującego m.in. także konflikty o charakterze wewnętrznym). Do $1949 \mathrm{r}$. w literaturze stosowano pojęcie prawa wojny (wojennego), po 1949 r. znacznie częściej występuje sformułowanie „międzynarodowe prawo humanitarne” (rekomendowane przez Międzynarodowy Komitet Czerwonego Krzyża) i występujące np. w dokumentach ONZ. Z kolei w doktrynie amerykańskiej stosuje się zwrot „prawo konfliktów zbrojnych” (ang. law of armed conflicts).

3 „Orzeczenie Stałego Trybunału Arbitrażowego z 4 IV 1928 r.," Island of Palmas Case (Netherlands, USA), Recueil Des Sentences Arbitrales, t. 2 (United Nations: 2006), 845.

4 Protokół dodatkowy do konwencji genewskich z 12 VIII 1949 r., dotyczący ochrony ofiar międzynarodowych konfliktów zbrojnych, Genewa, 8 VI 1977 r. (Dz. U. 1992, nr 41, poz. 175, załącznik).

$5 \quad$ Patrycja Grzebyk, Cele osobowe i rzeczowe w konfliktach zbrojnych w świetle prawa międzynarodowego (Warszawa: Wyd. Naukowe Scholar, 2018), 141. Cel wojskowy to w świetle międzynarodowego prawa humanitarnego legalny przedmiot ataku w warunkach konfliktu zbrojnego. Pod tym pojęciem kryją się cele osobowe (np. kombatanci) oraz niematerialne (np. pojazdy pancerne). 
badawcza związana $\mathrm{z}$ analizą prawnych aspektów bombardowań powietrznych w okresie II wojny światowej. Fundamentem wszelkich ustaleń w tej mierze powinna być próba odtworzenia stanu prawnego obowiązującego w latach 1939-1945.

Drugim problemem z perspektywy naukowej jest sam proces rekonstrukcji obowiązującego tła normatywnego. Istnieją poważne trudności z uwagi na swoisty dysonans pomiędzy różnego rodzaju deklaracjami, oświadczeniami czy też wręcz regulacjami państw przed okresem II wojny światowej (law in books) a zmiennym przebiegiem samego konfliktu, który ostatecznie przybrał charakter tzw. wojny totalnej (law in action). ${ }^{6}$ Płynne okoliczności pola walki oddziaływały także na prawo międzynarodowe, którego zmiany następowały z opóźnieniem.

Trzecie zagadnienie to wciąż niedostateczny stan wiedzy dotyczącej faktografii, wymagający współdziałania na płaszczyźnie historycznej oraz prawnej.

Celem niniejszego artykułu jest przedstawienie zarysu tła normatywnego obejmującego problem bombardowań powietrznych w okresie II wojny światowej, ze szczególnym uwzględnieniem nalotu dokonanego w dniu 1 września 1939 r. na przygraniczne miasto Wieluń. Pomimo prima facie historycznego charakteru wywodu, podkreślić należy, że „historia” w ujęciu ius in bello to $\mathrm{w}$ istocie zapis praktyki (przebiegu walk) o charakterze normotwórczym, a doświadczenia konfliktu wciąż wpływają na współczesne dokumenty międzynarodowego prawa humanitarnego.?

\section{Stan prawny prawa bombardowań powietrznych do $1914 \mathrm{r}$.}

Statków powietrznych używano na długo przed wynalazkiem braci Orville’a i Wilbura Wright z 1903 r., bowiem już w 1794 r. balony francuskiej

\footnotetext{
6 Zwłaszcza orzecznictwo Międzynarodowego Trybunału Karnego dla b. Jugosławii (MTKJ) (Wyrok Izby Orzekającej MTKJ z 14 I 2000 r., /IT-95-16/ Prosecutor v. Kupreškić et al., 207, par. 527) oraz Studium zwyczajowego międzynarodowego prawa humanitarnego Międzynarodowego Komitetu Czerwonego Krzyża z 2008 r. (Jean-Marie Henckearts, Studium poświęcone zwyczajowemu międzynarodowemu prawu humanitarnemu: wkład w zrozumienie i poszanowanie zasad prawa dotyczacych konfliktu zbrojnego, tłum. Michał Sajkowski /Warszawa: Drukarnia Janusz Bieszczad, 2006/, 11-13) bazują w pierwszej kolejności na ocenie oficjalnej („werbalnej”) narracji państwa (czyli law in books), potem na analizie rzeczywistego przebiegu działań wojennych (law in action). Podobny paradygmat nie przyświecał jednakże pracom Międzynarodowego Trybunału Wojskowego w Norymberdze (MTW), który w przedmiocie stosowania protokołu londyńskiego z 1936 r. (dot. akcji łodzi podwodnych), oparł się na dowodach przedstawiających faktyczne postępowanie stron podczas konfliktu, m.in. zeznaniach adm. Chestera Nimitza zob. Trial of The Major War Criminals Before the International Military Tribunal, Nuremberg 14 November 1945 - 1 October 1946 (Nuremberg: International Military Tribunal, 1947), 311-312.

7 William Hays Parks, „Perspective and the Importance of History, Yearbook of International Humanitarian Law 14, (2011): 377.
} 
armii prowadziły misje zwiadowcze podczas wojny przeciwko I koalicji antyfrancuskiej. Właściwości aerostatów w sposób zdecydowany poprawiały się na przestrzeni XIX w., by pod koniec stulecia osiągnąć możliwość przenoszenia materiałów wybuchowych (dotyczyło to zwłaszcza sterowców). ${ }^{8}$ W 1899 r. dwór rosyjski skierował do społeczności międzynarodowej zaproszenie do wzięcia udziału w konferencji pokojowej, mającej m.in. dokonać próby kodyfikacji praw i zwyczajów obowiązujących podczas prowadzenia działań wojennych. ${ }^{9}$

W chwili rozpoczęcia obrad I konferencji pokojowej w Hadze stan techniki lotniczej był już na tyle zaawansowany, że można było realnie rozważać jej przydatność wojskową. Stąd też w nocie dyplomatycznej dworu carskiego wskazano, aby na konferencji przedyskutować „wprowadzenie zakazu zrzucania z balonów (lub innych podobnych środków) jakichkolwiek ładunków wybuchowych bądź pocisków". ${ }^{10}$ Efektem podjętych rozmów było przyjęcie tymczasowego moratorium względem bombardowań powietrznych, które miało obowiązywać jedynie przez 5 lat w formie IV deklaracji haskiej z 1899 r. o zakazie zrzucania z balonów pocisków bądź materiałów wybuchowych. ${ }^{11}$ Deklaracją związały się 24 państwa, w tym wszystkie najważniejsze potęgi militarne tamtego okresu, $\mathrm{z}$ wyłączeniem Zjednoczonego Królestwa i Turcji. ${ }^{12}$

Na II konferencji pokojowej w Hadze (1907 r.) rozważano przedłużenie jej obowiązywania. Warto zwrócić uwagę, że okres zaledwie siedmiu lat był dostateczny do jednoznacznego potwierdzenia wojskowej przydatności

8 Mateusz Piątkowski, Wojna powietrzna a międzynarodowe prawo humanitarne (Łódź: Wyd. Uniwersytetu Łódzkiego, 2021), 32-33.

9 Teresa Dunworth, Humanitarian Disarmament: An Historical Enquiry (Cambridge: Cambridge University Press, 2010), 23-25.

10 Alexander Pearce Higgins, The Hague Peace Conferences and Other International Conferences Concerning The Laws and Usages of War: Texts of Conventions with Commentaries (Cambridge: Cambridge University Press, 1909), 40. Declaration (IV,1), to Prohibit, for the Term of Five Years, the Launching of Projectiles and Explosives from Balloons, and Other Methods of Similar Nature. The Hague, 29 July 1899, dostęp wrzesień 19, 2021, https://ihl-databases.icrc.org/ihl/INTRO/160?OpenDocument.

11 Wiesław Marud, „Bombardowania lotnicze z perspektywy prawa międzynarodowego,” Zeszyty Naukowe AON 81, nr 4 (2010): 132-133.

12 W przypadku Wielkiej Brytanii powód wynikał z czynników geograficznych. Państwo to upatrywało w rozwoju lotnictwa wojskowego zarówno szanse, jak i zagrożenia. Z jednej strony lotnictwo sprawiało, że Wyspy Brytyjskie mogły stać się miejscem prowadzenia działań wojennych, $\mathrm{z}$ drugiej zaś przyszłe brytyjskie siły powietrzne byłyby nowym argumentem natury strategicznej, otwierając możliwości szerszego oddziaływania na Europę kontynentalną. W późniejszym okresie, w ramach tzw. air policy, lotnictwo wojskowe okazało się być także narzędziem działań stabilizacyjnych w brytyjskich koloniach. 
lotnictwa. ${ }^{13} \mathrm{Z}$ tego też względu państwa tworzące własne siły powietrzne przestały być zainteresowane istnieniem zakazu bombardowań lotniczych. ${ }^{14} \mathrm{~W}$ efekcie, przedłużająca zakaz z 1899 r. XIV deklaracja haska została ratyfikowana jedynie przez Wielką Brytanię oraz Stany Zjednoczone. ${ }^{15}$ Okres obowiązywania został przewidziany do czasu zwołania kolejnej (III) konferencji pokojowej w Hadze. ${ }^{16}$ Ponieważ zdarzenie to nigdy nie nastąpiło, z technicznego punktu widzenia XIV deklaracja haska z $1907 \mathrm{r}$. obowiązuje państwa-strony do dziś. Jest to szczególnie interesująca obserwacja w kontekście Stanów Zjednoczonych i Wielkiej Brytanii, a więc państw posiadających rozbudowane siły powietrzne w okresie I i II wojny światowej. ${ }^{17}$ Jednakże już przed wybuchem I wojny światowej podważano wartość normatywną deklaracji z 1899 i 1907 r., wskazując, że zaistniał względem nich stan utraty mocy obowiązującej normy prawnej poprzez przeciwną praktykę (desuetudo). ${ }^{18} \mathrm{~W}$ konsekwencji uznaje się, że deklaracja nie posiada współcześnie żadnej wartości normatywnej, a mogła ją utracić jeszcze przed okresem I wojny światowej, gdy praktyka państw dopuściła bombardowania powietrzne jako legalną metodę prowadzenia działań wojennych. ${ }^{19}$

13 W 1900 r. pierwszy lot odbył sterowiec LZ 1 barona Ferdynanda von Zeppelina, a rok później brazylijski wynalazca Alberto Santos-Dumont wygrał konkurs „Deutsch de la Muerthe” polegający na oblocie wieży Eiffela w określonym czasie. W 1903 r. pierwszy lot samolotem cięższym od powietrza został przeprowadzony na samolocie Flyer One konstrukcji braci Wright, w 1906 r. Santos-Durmot na płatowcu własnej konstrukcji dokonał przelotu w obecności wielu mieszkańców Paryża, ustanawiając rekord długości lotu.

14 Howard S. Leroy, „Limitation of Air Warfare,” Air Law Review 12, (1941): 24.

15 Declaration (XIV) Prohibiting the Discharge of Projectiles and Explosives from Balloons. The Hague, 18 October 1907, dostęp wrzesień 19, 2021, https://ihl-databases.icrc.org/ ihl/INTRO/245. Zmiana pozycji Wielkiej Brytanii wynikała w 1907 r. z obawy przed utratą geograficznej przewagi jako państwa wyspiarskiego względem innych państw w Europie.

16 Jeremy Rabkin, „The Strange Pretensions of Contemporary Humanitarian Law," w Rethinking the Law of Armed Conflict in an Age of Terrorism, red. Christopher Ford i Amichai Cohen (Plymouth: Lexington Books, 2012), 45.

17 Rules of Land Warfare FM 27-10 (Washington: United States Government Printing Office, 1947), 8.

18 International Law - The Conduct of Armed Conflict and Air Operations (110-31) (Washington: United States Air Force, 1976), 5-1; „The United States Military Tribunal trying the I.G. Farben Trial has shown a willingness to admit that changing international custom may render a rule of law obsolete and so take away its obligatory nature." Law Reports of Trials of War Criminals: Selected and Prepared by The United Nations War Crimes Commission, t. 10, The I.G. Farben and Krupp Trials, (London: The United Nations War Crimes Commision By His Majesty's Stationery Office, 1949), 67.

19 Yoram Dinstein, „Air Warfare," w The Law of Armed Conflict and the Use of Force: The Max Planck Encyclopedia of Public International Law: Thematic Series Volume 2, red. Frauke Lauchenman i Ruediger Wolfrum (Oxford: Oxford University Press, 2017), 14. Przykładowo 
Brak zainteresowania ze strony państw w przedmiocie przedłużenia obowiązywania XIV deklaracji haskiej z 1907 r. wynikał jeszcze z jednego niezwykle istotnego czynnika. Podczas dyskusji nad zagadnieniem ataków lotniczych delegacje rosyjska i francuska zaproponowały, aby zamiast przyjąć czasową regulację o charakterze zakazującym, dokonać zmian w treści regulaminu haskiego dot. praw i zwyczajów obowiązujących w wojnie lądowej z 1899 r. i tym samym ograniczyć zakres dopuszczalnego bombardowania powietrznego. ${ }^{20}$ Kluczowa $\mathrm{w}$ tej mierze była zmiana treści art. $25 \mathrm{ww}$. regulaminu. W pierwotnym brzmieniu przepis stanowił, że niedopuszczalne jest „atakowanie lub bombardowanie bezbronnych wsi, domów mieszkalnych i budowli”. Podczas prac przygotowawczych z powszechną akceptacją delegatów spotkała się propozycja uzupełnienia treści zakazu o sformułowanie „bombardowanie w jakibądź sposób”. ${ }^{21} \mathrm{~W}$ ten sposób starano się powiązać prawo bombardowań powietrznych $\mathrm{z}$ wymogami obowiązującymi w wojnie lądowej. Prace przygotowawcze jednoznacznie potwierdzają, że zwrot „w jakibądź sposób” odnosił się do lotnictwa jako narzędzia ataków na obszary położone na lądzie. ${ }^{22}$

\section{Krytyczny błąd}

Podkreślić należy, że podczas II konferencji pokojowej w Hadze w 1907 r. rozpatrywano także zagadnienie bombardowań morskich. Podjęto decyzję, aby kwestię ataków morskich na obszary znajdujące się na lądzie unormować odrębną umową międzynarodową. Podstawowym czynnikiem, który wpłynął na powyższy sposób procedowania, była techniczna odmienność działania okrętów. Zwrócono uwagę, że reżim bombardowań artyleryjskich w pierwszej kolejności obejmował tzw. bombardowanie okupacyjne mające na celu doprowadzenie do złamania oporu obszaru bronionego i zajęcia go. W przypadku wojny morskiej wskazano, że siły morskie nie posiadają technicznej możliwości okupowania obszarów lądowych - w związku z tym ich wkład do walki na lądzie może być jedynie ograniczony do niszczenia obiektów ogniem dział

w 1914 r. Zygmunt Cybichowski określił, że „znaczenie umowy jest bardzo małe”, zob. Zygmunt Cybichowski, Międzynarodowe prawo wojenne: $Z$ uwzględnieniem przesilenia bałkańskiego (Lwów: Gubrynowicz i Syn, 1914), 42.

20 Roland Bechoff, „Laviation et les lois de la guerre," Revue générale de droit aérien 1, (1932): 530.

21 Konwencja (IV) dotycząca praw i zwyczajów wojny lądowej wraz z regulaminem dotyczącym praw i zwyczajów wojny lądowej (Dz. U. 1927, nr 21, poz. 161).

22 W. Thomas Mallison, „Studies in the Law of Naval Warfare: Submarines in General and Limited Wars," International Law Studies 58, (1966): 176. 
okrętowych (tzw. bombardowanie destrukcyjne). ${ }^{23} \mathrm{~W}$ tym celu w art. 2 IX konwencji haskiej z 1907 r. o bombardowaniach morskich ustanowiono wyjątek od zakazu atakowania obszarów niebronionych, jeżeli przedmiotem ataku są „dzieła wojskowe”, a mówiąc językiem współczesnego prawa międzynarodowego, „cele wojskowe”. ${ }^{24}$ Przepis tworzył enumeratywny katalog infrastruktury typu wojskowego, której zniszczenie jest dopuszczalne, nawet jeżeli miejscowość bądź inny obszar zurbanizowany jest niebroniony. ${ }^{25}$

Dokonując słusznego rozdzielenia reżimów bombardowania lądowego i morskiego, z nieznanych powodów zdecydowano się zakwalifikować bombardowanie lotnicze jako podtyp bombardowania lądowego. Był to krytyczny błąd (nazwany przez Burrusa Carnahana „absurdem”), mający bardzo poważne konsekwencje w przyszłości. ${ }^{26}$ Podstawą tego błędu było niedostrzeżenie realiów wojny powietrznej. Podobnie jak w przypadku okrętów, samolot wojskowy nie ma możliwości „okupowania” obszaru zabudowanego. ${ }^{27}$ Jego efektywna wartość wojskowa opiera się na zdolności niszczenia celów. W przypadku wojny lądowej, jeżeli miejscowość była niebroniona, ale znajdowała się w niej infrastruktura wojskowa, to nie istniało ratio przemawiające za niszczeniem obiektów natury militarnej, skoro mogły one zostać zajęte przez wojska lądowe. Należy zwrócić uwagę także na kontekst taktyczny regulaminu haskiego z 1907 r., który przewidywał, że działania wojenne będą ograniczone jedynie do bezpośredniej strefy kontaktu bojowego. Nie uwzględniono ( $\mathrm{z}$ uwagi na niewielką donośność artylerii lądowej) możliwości prowadzenia działań w wymiarze strategicznym, które stały się jednym z ważniejszych wymiarów działań lotnictwa wojskowego po $1918 \mathrm{r}$. W związku z powyższym test możliwości obrony danej miejscowości przed działaniem sił powietrznych jest zupełnie nieprzydatny, gdyż może być on jedynie relewantny co do działań artylerii lądowej w rozumieniu

23 Robert W. Tucker, The Law of War and Neutrality at Sea (Washington: United States Government Printing Office, 1957), 143.

24 Oświadczenie rządowe z 28 XI 1935 r. w sprawie przystąpienia Polski i szeregu państw do konwencji o bombardowaniu przez morskie siły zbrojne w czasie wojny $\mathrm{z}$ dn. $18 \mathrm{X}$ 1907 r., oraz jej ratyfikacji (Dz. U. 1936, nr 6, poz. 66).

25 Były to: „dzieła wojskowe, zakłady wojskowe lub morskie, składy broni lub sprzętu wojennego, warsztaty i instalacje, mogące być użyte dla potrzeb floty lub armji nieprzyjacielskiej oraz okręty wojenne, znajdujące się w porcie". Ibid.

26 Bruce M. Carnahan, „The Law of Air Bombardment in Its Historical Context," The Air Force Law Review 17, nr 2 (1975): 43 i n.

27 Horace B. Robertson, „1907 Hague Convention IX Concerning Bombardment by Naval Forces in Time of War," w The Law of Naval Warfare: A Collection of Agreements and Documents with Commentaries, red. Natalino Ronzitti (Dordrecht: Martinus Nijhoff Publishers, 1988), 164. 
taktycznym. ${ }^{28} \mathrm{~W}$ kontekście lotniczym stosowanie powyższego testu może prowadzić do kuriozalnych i nieakceptowanych wniosków, a przede wszystkim umożliwia dokonanie niemal dowolnej wykładni brzmienia przepisu. ${ }^{29}$ W skrajnym znaczeniu za „bronioną” należy uznać każdą miejscowość znajdującą się poza linią frontu, na zapleczu wroga. Kuriozalna interpretacja nakazuje traktować jako "niebronione” fabryki zbrojeniowe położone z dala od strefy czynnych walk i nieposiadające środków obrony przeciwko lotnictwu, a za „bronione” miasto pełne ludności cywilnej, bronione przez pojedynczą baterię artylerii przeciwlotniczej. ${ }^{30}$ Powyższy przykład doskonale ilustruje także zupełnie odmienny kontekst zwrotu „niebronione” w odniesieniu do wojny lądowej i powietrznej. ${ }^{31}$

W działaniach powietrznych sformułowanie „obszar broniony” ma wiele uzasadnionych znaczeń. Może obejmować nie tylko obecność wrogich oddziałów lądowych, ale także rozmieszczenie na danym terenie stanowisk artylerii przeciwlotniczej. Do swoistego „rozmydlenia” pojęcia dochodzi w przypadku uwzględnienia oddziaływania lotnictwa myśliwskiego (przechwytującego), co prowadzi do przyjęcia, że całość obszaru adwersarza jest $\mathrm{w}$ istocie „broniona” przed atakiem lotniczym. Nie zmieniała tej okoliczności praktyka uznawania pewnych miejscowości za tzw. „miasta otwarte”. Sens tej jednostronnej deklaracji miał znaczenie tylko w kontekście działań taktycznych, kiedy miejscowość mogła być faktycznie zajęta bez oporu przez przeciwnika i znajdowała się w zasięgu jego lądowego oddziaływania. ${ }^{32}$ Natomiast wręcz pewnym oksymoronem jest traktowanie za "miasta otwarte” obszarów znajdujących się poza linią frontu. ${ }^{33}$ Takie miasto jest siłą rzeczy niedostępne dla natychmiastowego zajęcia przez wojska lądowe, a przed bombardowaniem z powietrza nie chroni go (pod względem praw-

28 Frank Quindry, „Aerial Bombardment of Civilian and Military Objectives,” Journal of Air Law and Commerce 2, (1931): 484.

29 Dieter Fleck, „Strategic Bombing and the Definition of Military Objectives," Israel Yearbook on Human Rights (IYHR) 27, (1997): 43.

30 Mateusz Piątkowski, „Przepisy IV Konwencji haskiej z 1907 r. w świetle wojny powietrznej," Polski Przegląd Stosunków Międzynarodowych 3, (2013): 126-127.

31 Remigiusz Bierzanek, Wojna a prawo międzynarodowe (Warszawa: Wyd. Ministerstwa Obrony Narodowej, 1982), 301.

32 Przykładami powyższych deklaracji (złożonych tuż przed wkroczeniem wojsk nieprzyjacielskich) było oświadczenie dotyczące statusu Krakowa z dnia 5 IX 1939 r., Paryża w czerwcu 1940 r., Batawii w marcu 1942 r. oraz Hamburga w maju 1945 r. Wszystkim tym deklaracjom towarzyszył fakt rozsądnej bliskości czasowej pomiędzy ogłoszeniem a zajęciem miasta przez nadciągającego adwersarza.

33 W tych okolicznościach (tj. obecności oczywistych celów wojskowych i sił broniących dostępu do miasta) ogłoszono za „otwarte” m.in. Manilę w 1941 r. oraz Rzym w sierpniu 1943 r. H. Wayne Elliot, „Open Cities and (Un)defended Places,” The Army Lawyer, (1995): 45. 
nym) sam fakt braku obecności formacji wojskowych czy też garnizonu, lecz również brak innych celów wojskowych. ${ }^{34}$

Uznanie danego obszaru za „broniony” miało jeszcze jedną, niezwykle istotną konsekwencję, która została przemilczana w większości opracowań. ${ }^{35} \mathrm{~W}$ przypadku, w którym miejscowość była obsadzona przez nieprzyjaciela i stawiała opór przed zajęciem, dowodzący atakiem miał prawo do bombardowania całości obszaru zabudowanego, a nie tylko miejsc oporu. ${ }^{36}$ Stanowisko to potwierdziła praktyka wszystkich państw w okresie II wojny światowej, także co do konwencjonalnego ataku (lądowego) na obszary bronione. ${ }^{37}$ Ratio wynikało $\mathrm{z}$ ówczesnego przekonania o konieczności równomiernego rozdzielenia odpowiedzialności broniącego i atakującego za życie, zdrowie i mienie niewalczących. ${ }^{38}$

\section{Inne źródła prawa międzynarodowego odnoszącego się do bombardowań powietrznych}

Należy wspomnieć, za Trybunałem Wojskowym Stanów Zjednoczonych, że "prawo wojny to nie tylko traktaty, ale także zwyczaje i praktyka państwa, które osiągnęly powszechną akceptację, oraz ogólne zasady prawa stosowane przez prawników i sądy wojskowe.". ${ }^{39}$ Do ogólnych paradygmatów

34 United States Department of the Army, International Law, t. 2 (Washington: Department of the Army, 1962), 47.

35 Współcześnie międzynarodowe prawo humanitarne kategorycznie zabrania traktowania całych obszarów zabudowanych jako cel - stąd też w opracowaniach po II wojnie światowej nie wspomina się o art. 25 regulaminu haskiego z 1907 r. oraz jego wykładni, traktując to jako problem historyczny i przez to pomijany.

36 Charles Hyde, International Law Chiefly as and Applied by the United States (Boston: Little, Brown, and Company, 1922), 305.

37 Przykładami powyższych ataków, wykonywanych w sposób strefowy, przy użyciu artylerii lądowej, była m.in. bitwa o Caen (czerwiec-sierpień 1944 r.), która przyniosła zniszczenie ok. $80 \%$ zabudowy miejskiej.

38 William Hays Parks w swojej obszernej pracy poświęconej prawu wojny powietrznej uważa, że protokół dodatkowy I do konwencji genewskich z 1977 r. zaburzył istniejącą do pory przyjęcia dokumentu równowagę normatywną pomiędzy obowiązkami strony atakującej i broniącej w przedmiocie ochrony ludności cywilnej. Parks, „Air War and the Law of War," Air Force Law Review 32, (1990): 153-154.

39 „The law of war is to be found not only in treaties, but in the customs and practices of States, which gradually obtained universal recognition, and from the general principles of justice applied by jurists and practised by military courts." Trials of War Criminals Before the Nuremberg Military Tribunals, t. 6, „The Flick Case” (Washington: United States Government Printing Office, 1952), 1050. W Norymberdze przed Międzynarodowym Trybunałem Wojskowym odbył się tylko jeden proces: głównych autorów wojny, zakończony wyrokiem z dnia 1 X $1946 \mathrm{r}$. Z uwagi na rozłam wśród aliantów pozostałych 12 procesów (zwanych także następczymi procesami norymberskimi) odbyło się przed Trybunałem Wojskowym 
prawa wojny odwołały się mieszane trybunały arbitrażowe w orzeczeniach zapadłych na gruncie "Kiriadolou” i „Coenca” dotyczących bombardowań powietrznych w okresie I wojny światowej. ${ }^{40} \mathrm{~W}$ sprawie "Coenca” niemiecko-grecki mieszany trybunał arbitrażowy wskazał, że bombardowanie nocne Salonik przez niemieckie sterowce w 1916 r. nie było do pogodzenia $\mathrm{z}$ „ogólną zasadą prawa międzynarodowego, jaką jest poszanowanie ludności cywilnej i dóbr cywilnych". ${ }^{41} \mathrm{~W}$ tym orzeczeniu (oraz zapadłym na tle podobnego stanu faktycznego rozstrzygnięciu w sprawie „Kiriadolou”) trybunały zastosowały względem bombardowania lotniczego przepisy regulaminu haskiego z 1907 r., powielając „krytyczny błąd” wspomniany w podrozdziale powyżej, co zdecydowanie osłabia spójność tych orzeczeń. Dokonując przeglądu wydarzeń historycznych okresu międzywojennego w kontekście działań lotniczych, należy zaznaczyć, że o ile oświadczenia i zróżnicowane formy aktywności państw opowiadały się za jak najszerszą ochroną ludności cywilnej, to rzeczywisty przebieg działań powietrznych $\mathrm{w}$ okresie międzywojennym $\mathrm{z}$ tym stanowiskiem korespondował $\mathrm{w}$ niewielkim stopniu. Bombardowania o charakterze co najmniej kontrowersyjnym były codziennością w wojnie japońsko-chińskiej (np. bombardowanie powierzchniowe Chongqing w 1938 r.), ${ }^{42}$ napaści Włoch na Abisynię $e^{43}$ czy podczas konfliktu w Hiszpanii (z Guernicą na czele). ${ }^{44}$

W treści regulaminu haskiego z 1907 r. dot. praw i zwyczajów obowiązujących w wojnie lądowej można odnaleźć przepisy o charakterze

Stanów Zjednoczonych. Ustawa nr 10 Sojuszniczej Rady Kontroli Niemiec dała podstawy do tworzenia we wszystkich strefach okupacyjnych trybunałów mających sądzić niemieckich zbrodniarzy wojennych. Na zwołanie kolejnego międzynarodowego trybunału karnego społeczność międzynarodowa musiała oczekiwać aż do lat dziewięćdziesiątych XX w., gdy rezolucją Rady Bezpieczeństwa ONZ nr 827 z dnia 25 V 1993 r. powołano do życia Międzynarodowy Trybunał Karny dla b. Jugosławii.

40 Mieszane trybunały arbitrażowe zostały powołane mocą traktatu wersalskiego (art. 304) celem roztrząsania skarg indywidualnych $\mathrm{w}$ związku z poniesionymi szkodami w wyniku działań wojennych prowadzonych przez państwa centralne. Powstało blisko 36 takich trybunałów (np. Węgiersko-Czechosłowacki Mieszany Trybunał Arbitrażowy, Niemiecko-Grecki Mieszany Trybunał Arbitrażowy). Szacuje się, że trybunały rozpoznały prawie 70 tys. spraw w okresie międzywojennym. Mieszane trybunały arbitrażowe stosowały także prawo międzynarodowe, w tym ius in bello, jako podstawy do określenia naruszenia.

41 Cytat fragmentu orzeczenia w: Lessie C. Green, Essays on the Modern Law of War (New York: Transnational Publishers, 1985), 136.

42 Agnieszka Jachec-Neale, The Concept of Military Objectives in International Law and Targeting (New York: Routledge, 2015), 28.

43 Derrick M. Nault, Africa and the Shaping of International Human Rights (Oxford: Oxford University Press, 2020), 40.

44 Brett Holman, The Next War in the Air: Britain's Fear of the Bomber, 1908-1941 (Farnham: Ashgate Publishing Limited, 2014), 203. 
ogólnym, które potencjalnie mogły mieć zastosowanie względem bombardowań powietrznych. W pierwszej kolejności należy odnieść się do klauzuli Martensa, zamieszczonej w preambule do IV konwencji haskiej z 1907 r. o prawach i zwyczajach obowiązujących w wojnie lądowej jako swoistego "bezpiecznika” prawnego na wypadek, w którym normy ius in bello nie proponują szczegółowych rozwiązań. Należy podkreślić, że nawet po 80 latach od zakończenia II wojny światowej wartość normatywna klauzuli budzi wątpliwości i wiele przeważa za jej ograniczoną formą jako swoistej dyrektywy interpretacyjnej. ${ }^{45}$ Oczywiście warto odwołać się do stanowisk przeciwnych, inspirowanych stanowiskiem Trybunału Wojskowego Stanów Zjednoczonych w sprawie „Alfreda Kruppa”. ${ }^{46}$ Jednakże zdecydowana większość z tych poglądów była formułowana już wiele lat po II wojnie światowej, także pod wpływem równoległego rozwoju standardów ochrony praw człowieka. ${ }^{47}$ Same trybunały norymberskie były także niekonsekwentne

45 Zob. Teodor Meron, „The Martens Clause, Principles of Humanity and Dictates of Public Conscience," The American Journal of International Law 94, nr 1 (2000): 78-89. Wątpliwości w kontekście wartości normatywnej klauzuli były podnoszone m.in. w ramach postępowania przed Międzynarodowym Trybunałem Sprawiedliwości w Hadze, w związku z wydaniem opinii doradczej dotyczącej legalności groźby lub użycia broni jądrowej w 1996 r. Państwa posiadające $\mathrm{w}$ swym arsenale broń jądrową podniosły, że klauzula nie może być traktowana jako autonomiczne źródło prawa wprost zakazujące posiadania tego typu uzbrojenia. Sam Trybunał w kontekście broni jądrowej określił, że klauzula przypomina o tym, że każda broń podlega rygorom międzynarodowego prawa humanitarnego (Legality of the Threat or Use of Nuclear Weapons, Advisory Opinion, I.C.J. Reports 1996, \$ 87). Podkreśla się w literaturze, że klauzula była rozwiązaniem „ratunkowym” zaproponowanym przez ówczesnego przewodniczącego rosyjskiej delegacji podczas obrad w Hadze w 1899 r., która miała na celu skłonienie mniejszych państw do poparcia projektu konwencji i regulaminu haskiego, uznających zaproponowany reżim okupacji zbrojnej za niekorzystny i mających formę bardziej odesłania do norm prawa naturalnego oraz przypomnienia faktu równoległej egzystencji prawa traktatowego i norm prawa zwyczajowego (zob. Piątkowski, Wojna powietrzna, 124).

46 „The preamble is much more than a pious declaration. It is a general clause, making the usages established among civilized nations, the laws of humanity, and the dictates of public conscience into the legal yardstick to be applied if and when the specific provisions of the Convention and the Regulations annexed to it do not cover specific cases occurring in warfare, or concomitant to warfare" (tłum. M. P.: Preambuła nie jest tylko uroczystą deklaracją. Jest klauzulą generalną, ustanawiającą za drogowskaz prawny zwyczaje istniejące pomiędzy cywilizowanymi narodami, prawa ludzkości oraz wymagania społecznego sumienia, mające zastosowanie w sytuacji, gdy konwencja i regulamin nie regulują określonej sytuacji wojennej."). The I.G. Farben and Krupp Trials, 133.

47 Przyjęcie Powszechnej deklaracji praw człowieka przez Zgromadzenie Ogólne ONZ w 1948 r. było swoistym „katalizatorem” rozwoju praw człowieka, który zapoczątkował postęp tej gałęzi prawa w drugiej połowie XX w. zarówno na poziomie globalnym, jak i regionalnym. Rozwinięciem Deklaracji jest Międzynarodowy pakt praw obywatelskich i politycznych z 1966 r., natomiast w Europie w 1950 r. przyjęto Europejską konwencję o ochronie praw człowieka i podstawowych wolności. 
w stosowaniu klauzuli, nie wykorzystując jej w sprawach, w których brak wyraźnej normy zakazującej prowadził do sankcjonowania aktów zbrojnych trudnych do zaakceptowania $\mathrm{w}$ świetle paradygmatów określonych w ramach preambuły do regulaminu haskiego z 1907 r. dot. praw i zwyczajów wojennych (zob. sprawa stosowania przez okręty podwodne protokołu londyńskiego z 1936 r. oraz zagadnienie legalności blokady Leningradu). Klauzula sama w sobie nie stanowi i tym bardziej nigdy nie stanowiła narzędzia uzupełnienia luk w prawie pozytywnym, zwłaszcza nie mogła zastąpić szczegółowych i technicznych norm co do bombardowania powietrznego. ${ }^{48}$ Z klauzuli nie można odczytywać, w jaki sposób walczący mogą dokonywać ataków na obszary bronione bądź cele wojskowe. Próżno także odnaleźć zarówno w literaturze przedwojennej, jak i powojennej, jasnego odwołania się do klauzuli jako źródła prawa bombardowań powietrznych. ${ }^{49}$ Jak podkreślono w instruktażu Armii Stanów Zjednoczonych z zakresu prawa międzynarodowego, o ile pewne praktyki okresu I i II wojny światowej - jak wojna chemiczna czy też niehumanitarne traktowanie jeńców wojennych - zostały potępione jako naruszające ogólny aksjomat wynikający z zasady humanitaryzmu i praw ludzkości, o tyle „powierzchniowe bombardowania powietrzne w okresie II wojny światowej nie wzbudziły większego poruszenia względem opinii publicznej”. ${ }^{50}$

\section{Haskie reguły wojny powietrznej z $1923 \mathrm{r}$. - prawo czy propozycja prawa?}

Przebieg I wojny światowej w całości potwierdził nieprzydatność art. 25 regulaminu haskiego z 1907 r. w warunkach wojny powietrznej. Już w trakcie konfliktu pojawiały się pewne „ratunkowe” sposoby jego interpretacji m.in. poprzez odwołanie się do IX konwencji haskiej z 1907 r., odnoszącej się do bombardowań morskich. ${ }^{51}$ Jednocześnie w 1918 r. działania lotnicze

48 Tak np. Zbigniew Rotocki oceniał hierarchiczne miejsce klauzuli Martensa za innymi „pomocniczymi normami” (auxiliary norms) prawa wojny powietrznej. Zbigniew Rotocki, „Polish Directives of 1939 Concerning Aerial Bombardment in the Light of International Rules of Air Warfare," Polish Yearbook of International Law 3, (1970): 149.

49 Ian Henderson, The Contemporary Law of Targeting (Leiden: Martinus Nijhoff Publishers, 2009): 31. Eberhard Spetzler wskazywał, że klauzula Martensa sugeruje zastosowanie regulaminu haskiego z 1907 r. względem wojny powietrznej, zwłaszcza maszyn prowadzących wsparcie bezpośredniego pola walki. Eberhard Spetzler, Luftkrieg und Menschlichkeit. Die völkerrechtlich Stellung der Zivilpersonen im Luftkrieg (Berlin: Musterschmidt, 1956), 131.

50 „Department of the Army Pamphlet,” International Law, t. 2 (Washington: United States Government Printing Office, 1962), 15.

51 Hersch Lauterpacht, The Function of Law in the International Community (New Jersey: The Lawbook Exchange, 2000), 73. 
miały już wymiar jednej z decydujących metod prowadzenia walki, poprzez zdolność do wykonywania uderzeń strategicznych i efektywnego wspierania wojsk lądowych..$^{52}$ Ewentualna delegalizacja bombardowań powietrznych stała się utopią wobec realiów technicznych i geopolitycznych. Jednakże powszechnie zdawano sobie sprawę, że prawo międzynarodowe obowiązujące w czasie wojny wymagało głębokiej rewizji. ${ }^{53} \mathrm{~W} 1922 \mathrm{r}$, podczas waszyngtońskiej konferencji rozbrojeniowej, podjęto decyzję o powierzeniu grupie prawników i doświadczonych oficerów lotnictwa misji stworzenia „kodeksu" wojny powietrznej. Efektem pracy ekspertów pod przewodnictwem sędziego Stałego Trybunału Sprawiedliwości Międzynarodowej Johna Basseta Moora było przygotowanie projektu, znanego powszechnie jako haskie reguły wojny powietrznej z $1923 \mathrm{r}^{54}$

Projekt miał być pełną regulacją prawa wojny powietrznej. W dokumencie dokonano kodyfikacji norm o charakterze zwyczajowym (potwierdzonym praktyką państw w okresie I wojny światowej), np. w zakresie definicji wojskowego statku powietrznego. Największym wyzwaniem dla ekspertów było określenie reżimu bombardowań powietrznych. Wprowadzone rozwiązania zrywały z testem "obronności” danego obszaru, zastępując go definicją "celów wojskowych” o charakterze abstrakcyjnym, wymagając zmaterializowania się „wyraźnej korzyści wojskowej” (art. 24). Stworzono przy tym zamknięty katalog obiektów o szerokim charakterze, obejmujący oprócz celów osobowych także infrastrukturę produkcyjną oraz transportową o przeznaczeniu militarnym. ${ }^{55}$ Reguły dążyły do ograniczenia zakresu bombardowania obszarów położonych $\mathrm{z}$ dala od linii frontu, zezwalając jedynie na ataki względem celów wojskowych (wyszczególnionych w art. 24 ust. 2), ale pod warunkiem, że nie będzie to bombardowanie powierzchniowe („bez rozróżnienia”). ${ }^{56} \mathrm{~W}$ przypadku obszarów położonych bliżej linii frontu dopuszczano szerszy charakter ataków, pod warunkiem „uzasadnionej koncentracji wojskowej" $\mathrm{z}$ uwzględnieniem niebezpieczeństwa wynikającego z tego tytułu dla ludności cywilnej. Rozróżnienie na bombardowanie

52 Przykładem takich ataków jest seria nalotów niemieckich bombowców Gotha na Wyspy Brytyjskie latem 1917 r., a ze strony brytyjskiej przykładem powyższego działania był atak wykonany już 21 XI 1914 r. na fabryki Zeppelinów w południowych Niemczech.

53 Sarah McCosker, „Domains of Warfare,” w The Oxford Guide to International Humanitarian Law, red. Ben Saul i Dapo Akande (Oxford: Oxford University Press, 2020), 84.

54 John B. Moore, International Law and Some Current Illusions: And Other Essays (New York: Macmillan, 1924), 182 i n.

55 Piątkowski, „Security of the Civilian Population From the Consequences of Aerial Warfare in The Light of the Hague Rules of Aerial Warfare of 1923," w $3^{\text {rd }}$ International Conference of PhD Students and Young Researcher Security As a Purpose of Law, red. Gintare Tamašauskaitè-Janickè (Vilinus: Vilinus University, 2016), 185.

56 Moore, International, 242-243. 
poza linią frontu i w strefie bezpośredniej styczności bojowej może być odbierane jako nieuprawnione - jednakże w tym kontekście reguły doprowadziły do urealnienia stanu prawnego względem rzeczywistości pola walki. Należy zwrócić uwagę, że o ile szczegółowa analiza przepisów tworzy uzasadnione wątpliwości, czy też wręcz krytykę niektórych rozwiązań (np. nierealistyczny katalog celów wojskowych, brak jasnego podziału na bombardowania taktyczne i strategiczne), o tyle ad principio art. 22 i 24 haskich reguł wojny powietrznej stanowiły wielki postęp w stosunku do poprzedniego stanu prawnego. ${ }^{57}$

Analizę wartości normatywnej haskich reguł wojny powietrznej w przededniu II wojny światowej należy rozpocząć od przypomnienia, że dokument ten pozostał jedynie projektem. Paradoksalnie, pomimo że regułom z 1923 r. nie było dane przekształcić się w umowę międzynarodową, to dokument ten pozostał częścią „obiegu wewnętrznego" państw posiadających rozbudowane siły powietrzne. W 1928 r. w swym memorandum dowódca Królewskich Sił Powietrznych Hugh Trenchard ocenił, że „reguły z 1923 r. będą stanowiły wyznacznik tego co legalne w przyszłej wojnie powietrznej”. ${ }^{58} \mathrm{~W} 1938$ r., podczas wojny chińsko-japońskiej, Japonia wprost ogłosiła, że w swych działaniach powietrznych będzie stosowała haskie reguły wojny powietrznej. ${ }^{59}$ Włoskie ustawy „o wojnie i neutralności” z 1938 r. opierają się na tezach przedstawionych przez komisję jurystów w Hadze w 1923 r. ${ }^{60}$ Znamienny jest również fakt (podkreślany przez polskich badaczy - prof. Remigiusza Bierzanka i Zbigniewa Rotockiego) wydania w przededniu wojny przez najwyższe polskie władze wojskowe wytycznych dotyczących bombardowania powietrznego. Podkreślić należy, że dokument został "uzgodniony z rządem francuskim i angielskim” i w znacznej mierze dokonał przeniesienia głównych założeń reguł z 1923 r. ${ }^{61}$ Powyższe

57 Szeroką krytykę reguł z 1923 r. przedstawił Parks, określając dokument jako „całkowitą porażkę" (ang. total failure), nieprzystającą do realiów działań powietrznych, nakładający nierealistyczne obowiązki na bombardującego. Parks, „Air War,” 31-35.

58 Cyt. za: Paul J. Goda, „The Protection of Civilians from Bombardment by Aircraft: The Ineffectiveness of the International Law of War," Military Law Review 33, nr 93 (1966): 99.

59 Hamilton DeSaussure, „The Laws of Air Wafare: Are There Any?” International Law Studies 62, nr 1 (1977): 282.

60 Natalino Ronzitti, „The Codification of Law of Air Warfare," w The Law of Air Warfare: Contemporary Issues, red. Natalino Ronzitti i Gabriela Venturini (Utrecht: Eleven International Publisher, 2006), 7.

${ }_{61}$ Remigiusz Bierzanek, „1923 Hague Rules: Commentary,” w The Law of Naval Warfare: A Collection for Agreements and Documents with Commentaries, red. Natalino Ronzitti (Haga: Brill, 1988), 404-405. Zob. Piątkowski, „Prawo międzynarodowe konfliktów zbrojnych i działalność polskiego lotnictwa wojskowego we wrześniu 1939 roku w świetle wytycznych najwyższych władz wojskowych," w Szkice $z$ historii lotnictwa polskiego, t. 2, Udział 
działania mogą być dowodem zarówno usus, jak i opinio iuris w kontekście zwyczaju międzynarodowego. ${ }^{62}$ Paradoksalnie, działania te nie obejmowały wyłącznie państw alianckich. Zgodnie z materiałami zebranymi przez niemieckiego badacza, Heinza Markusa Hanke, w niemieckich archiwach znajduje się rozkaz Hansa Jeschonnka z 22 lipca 1939 r., który nakazywał Luftwaffe ogólne stosowanie się do teorii „celu wojskowego”, zawierający jednakże znamienny fragment odnoszący się do możliwości odstąpienia od reguł na rozkaz głównodowodzącego. ${ }^{63}$ Jednym $\mathrm{z}$ najbardziej reprezentatywnych przykładów powszechnego opinio iuris jest rezolucja Ligi Narodów z 30 sierpnia 1938 r., jednoznacznie potępiająca praktykę nalotów saturacyjnych, umyślnie wymierzonych w ludność cywilną bądź takich, które nie są skierowane przeciwko celom wojskowym. ${ }^{64}$ Powyższy fragment warto zamknąć przypomnieniem odezwy prezydenta Franklina Delano Roosevelta z 1 września 1939 r. kierowanej do stron konfliktu, aby powstrzymały się od bombardowań skierowanych przeciw ludności cywilnej. ${ }^{65}$

Należy wskazać, że przedstawione powyżej dowody praktyki „najbardziej zaangażowanych państw" (posiadających najsilniej rozbudowane floty powietrzne), wyrażone poprzez rozkazy i instrukcje wojskowe, posiadały także podbudowę prawną, prima facie tworząc tym samym niezbędne elementy dla powstania prawa zwyczajowego. ${ }^{66}$ Powyższe stwierdzenie skłoniło

Lotnictwa w walce o niepodległość na frontach II wojny światowej oraz wybrane aspekty funkcjonowania współczesnych sił powietrznych, red. Adam Radomyski, Krzysztof Ogonowski i Andrzej Olejko (Dęblin: Wyższa Szkoła Oficerska Sił Powietrznych, 2017), 27-39.

62 Rotocki, „Polish Directives,” 153.

63 Heinz Marcus Hanke, „The 1923 Hague Rules of Air Warfare: A Contribution To The Development of International Law Protecting Civilians From Air Attack," International Review of the Red Cross, nr 292 (1993): 35.

64 Tekst rezolucji za: Dieter Schindler i Jiri Toman, The Laws of Armed Conflicts: A Collection of Conventions, Resolutions and Other Document (Dordrecht: Marinus Nijhoff Publishers, 1988), 221-222.

65 „An Appeal to Great Britain, France, Italy, Germany, and Poland to Refrain from Air Bombing of Civilians. Online by Gerhard Peters and John T. Woolley, The American Presidency Project," dostęp wrzesień 21, 2021, https://www.presidency.ucsb.edu/node/209957.

66 Peter Grey, Air Warfare: History, Theory and Practice (London: Bloomsbury, 2016), 88-89. Prawo zwyczajowe to jedno ze źródeł prawa międzynarodowego. Definicja zwyczaju określa go jako „dowód istnienia powszechnej praktyki, przyjętej jako prawo” (art. 38 ust. 1 lit. b Statutu Międzynarodowego Trybunału Sprawiedliwości, Dz. U. 1947, nr 23, poz. 90). Konkretnymi przejawami praktyki państw (usus) są zachowania bądź zaniechania (np. egzekwowanie swojej neutralności poprzez aktywne przeciwstawianie się naruszeniom przestrzeni powietrznej bądź morza terytorialnego), treść ustawodawstwa wewnętrznego (np. rozporządzenie Prezydenta RP z 1932 r. o ustanowieniu granicy morskiej państwa i szerokości polskiego morza terytorialnego wynoszącego 3 mile morskie), rozstrzygnięcia sądów oraz organów administracji dotyczące stosunków międzynarodowych (np. immunitetu jurysdykcyjnego państwa), jak również umowy międzynarodowe (zwłaszcza jeżeli posiadają wręcz 
kilku autorów, a także Sąd Okręgowy w Tokio w sprawie "Shimoda v. Japan” (kilkadziesiąt lat po zakończeniu II wojny światowej) do zaaprobowania zwyczajowego charakteru regulacji z 1923 r. ${ }^{67}$ Jednakże cieniem na wartość normatywną ww. dokumentu położył się przebieg całej II wojny światowej, stopniowe odstępowanie przez wszystkie strony konfliktu od restryktywnej definicji celu wojskowego i generalnej zasady poszanowania niewalczących. ${ }^{68}$ Dopuszczalne w tej mierze było nawet przyjęcie tzw. efektu kumulatywnego - czyli „strategicznego” pojmowania „korzyści wojskowej”. ${ }^{69}$ Celem wojskowym było także oddziaływanie na morale ludności cywilnej. ${ }^{70}$ Działania $\mathrm{w}$ tej mierze zapoczątkowała strona niemiecka, prowadząc ataki lotnicze przeciwko miejscowościom w Polsce, kontynuując bezlitosne naloty na obszary zurbanizowane w Holandii, Wielkiej Brytanii, Jugosławii, ZSRR. Od 1942 r. również strona aliancka (poprzez przyjęcie tzw. Area Bombing Directive) rozpoczęła strefowe naloty na miasta Osi. ${ }^{71}$ Innymi czynnikami, które wpływały na stopniowe zacieranie się różnić pomiędzy walczącymi

uniwersalny charakter). Drugim niezbędnym elementem zwyczaju jest opinio iuris - czyli przekonanie o zgodności praktyki z prawem. Zachowania państw winny oprócz praktyki wykazywać, że ich aktywność jest wynikiem zobowiązania prawnego. Nie stanowią przejawu opinio iuris okoliczności, w których państwa działają na podstawie przesłanek pozaprawnych, np. propagandowych, politycznych lub kurtuazyjnych. W badaniu aktywności państw może dochodzić do zbiegu obydwu elementów prawa zwyczajowego - np. instrukcja wojskowa jest przejawem nie tylko samej praktyki, ale jako akt normatywny także opinio iuris. Karol Wolfke, Custom in Present International Law (Wrocław: Zakład Narodowy im. Ossolińskich, 1964), 147.

67 „Wyrok Sądu Okręgowego w Tokio z 7 XII 1963 r.,” dostęp wrzesień 21, 2021, https:// ihl-databases.icrc.org/applic/ihl/ihl-nat.nsf/0/aa559087dbcf1af5c1256a1c0029f14d. Anthony D’Amaoto, International Law and Political Reality: Collected Papers Volume One (Haga: Martinus Nijhoff Publishers, 1995), 32; Henderson, The Contemporary, 26; Robert Nelson i Christopher Waters, „The Allied Bombing of German Cities during the Second World War from a Canadian Perspective," Journal of the History of International Law 14, (2012): 100; Hanke, „The 1923 Hague Rules,” 36.

68 Jeanne Meyer, „Tearing Down the Facade: A Criticial Look At The Current Law on Targeting The Will of The Enemy and Air Force Doctrine," The Air Force Law Review 51, (2001): 152. William J. Fenrick, „Applying IHL Targeting Rules To Practical Situations: Proportionality and Military Objectives," Windsor Yearbook of Access to Justice 27, (2009): 274.

69 Bernard Brown, „The Proportionality Principle in the Humanitarian Law of Warfare: Recent Efforts at Codification," Cornell International Law Journal 10, (1976): 141.

70 Chris Jochnick i Roger Normand, „The Legitimation of Violence: A Critical History of the Laws of War," Harvard International Law Journal 35, (1994): 87-88.

71 Pojęcie bombardowania strefowego (ang. area bombing) oznaczało, że o ile centralny punkt celowania był zidentyfikowany jako cel wojskowy, to z uwagi na realia techniczne przedmiotem nalotu była cała strefa, w której mogły znajdować się zarówno inne cele wojskowe, jak i niewojskowe. Alan J. Levine, The Strategic Bombing of Germany 1940-1945 (Westport: CT, 1992), 35-38; Michał Fiszer, Lotnictwo w osiaganiu celów strategicznych operacji militarnych (Warszawa: Trio, 2011), 121-122. 
a ludnością cywilną oraz rozszerzały definicje celów wojskowych, były techniczna niedostateczna dokładność bombardowania (np. rozrzut bomb wynoszący nawet ok. $1 \mathrm{~km}$ od celu uważano za akceptowalny), a także częsta praktyka (zwłaszcza w końcowym etapie wojny) celowego rozmieszczania produkcji przemysłowej $\mathrm{w}$ obszarach miejskich. ${ }^{72}$ Kombinacja przyczyn technicznych i operacyjnych, połączona $z$ brakiem jednoznacznego zarysu prawa bombardowań powietrznych, wprowadziła wojnę powietrzną do stanu zupełnej nieprzejrzystości, w której wszystko niemal dawało się usprawiedliwić działaniem przeciwnika, względami operacyjnymi, ${ }^{73}$ "godnymi pożałowania, lecz niezbędnymi” stratami ubocznymi (collateral damage ${ }^{74}$ oraz paradygmatem wojny totalnej. ${ }^{75}$ Odrębną kategorią w tej mierze jest również stosowanie swoistej koncepcji represaliów. ${ }^{76}$ Przybliża to obraz reżimu bombardowań powietrznych do zarysów wręcz stanu normy non-liquet (rzeczy niejasnej), trwający aż do $1977 \mathrm{r}^{77} \mathrm{Z}$ drugiej strony warto przywołać poglądy, które uznają, że zasada rozróżniania musiała „przetrwać” okres II wojny światowej, pomimo powszechnego jej ignorowania. ${ }^{78} \mathrm{Nie}$ można też stwierdzić (pomimo podobnych głosów ${ }^{79}$ ), że praktyka bombardowań saturacyjnych stała się prawem powstałym na kanwie praktyki państw w latach $1939-1945 .{ }^{80}$

72 Jachec-Neale, The Concept, 26-28; Eldridge Colby, „Laws of Aerial Warfare," Minnesota Law Review 10, (1925-1925): 208.

73 „The target of Bomber Command are always military, but night bombing of military objectives necessarily involves bombing the area in which they are situated." Cyt. za: John Ford, "The Morality of Obliteration Bombing," Theological Studies 5, nr 3 (1944): 262.

74 Jay Terry, „The Evolving Law of Aerial Warfare," Air University Review 37, nr 1 (1975): 33.

75 Horace B. Robertson Jr., "The Status of Civil Aircraft in Armed Conflict," IYHR 27, (1997): 123; Krzysztof Skubiszewski, „Prawo wojny i neutralności w świecie współczesnym,” Ruch Prawniczy, Ekonomiczny i Socjologiczny, nr 1 (1967): 121.

76 Rozpoczęcie bombardowania Londynu w trakcie bitwy o Anglię skutkowało nalotem brytyjskim na stolicę III Rzeszy. W dalszej części wojny skala alianckiej „Połączonej Ofensywy Bombowej" była uzasadniona niezwykle szeroką koncepcją represaliów, która wykraczała zdecydowanie w ujęciu sensu stricto poza standardy legalności represaliów, zakreślone na gruncie sprawy Naulilaa. Carnahan, „The Law, 53-54.

77 Josef Kunz, Kriegsrecht und Neutralitätsrecht (Berlin: Springer, 1935), 193; Parks, „The Protection of Civilians From Air Warfare," IYHR 27, (1997): 66-67; Yoram Dinstein, „The Thirteenth Waldemar A. Solf Lecture in International Law," Military Law Review 166, (2000): 104.

78 Stefan Oeter, „Means and Method of Warfare,” w The Handbook of International Humanitarian Law, red. Michael Bothe (Oxford: Oxford University Press, 2013), 401.

79 David Corwin, „The Legality of Nuclear Arms Under International Law, Penn State International Law Review 5, nr 2 (1987): 281.

80 Henri Meyrowitz, „Le bombardernent strategique d'apres le Protocole additionnel I aux Conventions de Geneve," Zeitschrift für ausländisches öffentliches Recht und Völkerrecht 41, (1981): 18; Zob. także treść telegramu Winstona Churchilla po ataku na Drezno w lutym 


\section{Wieluń - atak na miasto w świetle prawa międzynarodowego}

O godz. 4:40 1 września 1939 r. niemieckie samoloty Junkers Ju-87B Stuka z 76 Skrzydła Bombowców Nurkujących (niem. Sturmgeschwader - StG) pod dowództwem Hauptmanna Waltera Siegla rozpoczęły - w warunkach całkowitego zaskoczenia - nalot na Wieluń z użyciem bomb burzących i zapalających. Warto wspomnieć, że nalot o $4: 40$ był pierwszym z trzech. Pozostałe uderzenia wykonały maszyny 77 i 2 StG, a łącznie miasto zostało zaatakowane w ciągu całego dnia przez ponad 90 samolotów. W rezultacie ok. 75\% zabudowy miejskiej uległo zniszczeniu, a liczbę ofiar określono na co najmniej 127 zabitych. W trakcie śledztwa Oddziałowej Komisji Ścigania Zbrodni przeciwko Narodowi Polskiemu w Łodzi ustalono, że w chwili ataku w Wieluniu nie znajdowały się jednostki Wojska Polskiego. 36 Pułk Piechoty (pp) Legii Akademickiej z 28 Dywizji Piechoty (DP) wraz z Batalionami Obrony Narodowej i innymi jednostkami Oddziału Wydzielonego płk. Jerzego Grobickiego ze składu Armii (A) „Łódź” zostały rozmieszczone w pasie nadgranicznym, celem wykonania zadań osłonowych. ${ }^{81} \mathrm{~W}$ śledztwie wskazano m.in. na treść pogwałconych przez stronę niemiecką przepisów regulaminu haskiego z 1907 r. (art. 25) i wypełnienie znamion zbrodni wojennej określonej na gruncie art. 6 statutu Międzynarodowego Trybunału Wojskowego, polegającego na „bezmyślnym niszczeniu osiedli, miast lub wsi nie usprawiedliwionych koniecznością wojenną". ${ }^{82}$

1945 r., w którym przywódca brytyjski stwierdził, że „brytyjskie naloty powinny koncentrować się bardziej na celach wojskowych, niż na terrorze i rozmyślnym niszczeniu”. „Two drafts of a letter from Churchill on area bombing, 28 March 1945 and 1 April 1945," CAB 120/303. National Archives, dostęp październik 27, 2021, https://www.nationalarchives.gov. uk/education/leaders-and-controversies/transcript/g1cs3s3t.htm.

${ }^{81}$ Wysunięcie znacznej części jednostek WP na bezpośrednie pogranicze polsko-niemieckie było podyktowane także czynnikami polityczno-międzynarodowymi. Stawienie aktywnego oporu od pierwszych minut niemieckiej inwazji, obrona każdego metra terytorium były manifestacją zewnętrzną podjęcia wysiłku obrony państwa. Działania te miały w konsekwencji spowodować reakcje i uruchomienie zobowiązań państw sojuszniczych, które obawiały się powtórzenia scenariusza czechosłowackiego bądź austriackiego, czy też błyskawicznego przełamania oporu polskich sił zbrojnych. O ile ostatecznie osiągnięto sukces polityczny w postaci przystąpienia aliantów zachodnich do wojny, to militarnie doprowadzono do nadmiernego rozciągnięcia linii obronnych. Zob. art. 1 i art. 2 ust. 1 Układu o pomocy wzajemnej między Rzeczpospolitą Polską a Zjednoczonym Królestwem Wielkiej Brytanii i Irlandii Północnej z dnia 25 VIII 1939 r. (,The Avalon Project,” dostęp październik 27, 2021, https:// avalon.law.yale.edu/wwii/blbk19.asp).

82 Piątkowski, „Wieluń - 1 IX 1939 r. Bombardowanie miasta a międzynarodowe prawo konfliktów zbrojnych," Wojskowy Przegląd Prawniczy, nr 2 (2013): 21-53; Piątkowski, „Judging the past - international humanitarian law and the Luftwaffe aerial operations during the invasion of Poland in 1939," w International Humanitarian Law and Justice Historical and Sociological Perspectives, red. Mats Deland, Mark Klamberg i Paul Wrange (New York: 
Analiza zgodności ataku na Wieluń z ówcześnie obowiązującymi przepisami regulującymi prawo wojny powietrznej dobrze odzwierciedla wszelkie problemy związane ze stosowaniem w praktyce ww. przepisów, a zwłaszcza ujawnia się znacząca dowolność interpretacyjna art. 25 regulaminu haskiego z 1907 r. ${ }^{83}$ Wieluń znajdował się za linią styczności bojowej jednostek Wojska Polskiego działających na pograniczu polsko-niemieckim. Już w tym kontekście najbardziej daleko idąca wykładnia art. 25 regulaminu haskiego z 1907 r. klasyfikuje każdą miejscowość położoną poza linią frontu jako „bronioną". Drugim aspektem jest fakt obecności w okolicach miasta jednostek WP, które posiadały zdolność do rażenia (chociażby ogniem broni ręcznej) przelatujących formacji niemieckiego lotnictwa. Trzeci problem to fakt oddziaływania lotnictwa A „Łódź”, w postaci III Dywizjonu Myśliwskiego 6 Pułku Lotniczego stacjonującego na lotnisku w Widzewie (dziś część Łodzi). ${ }^{84}$ Zbieg tych okoliczności unaocznia problematyczność stosowania testu „obronności miejscowości” w warunkach wojny powietrznej.

Jeżeli ocenić bombardowanie z perspektywy przepisów haskich reguł wojny powietrznej (oczywiście zakładając hipotetycznie, że regulacja miała wymiar prawa obowiązującego przed wybuchem II wojny światowej) to należy pochylić się nad treścią art. 22 i 24 reguł z 1923 r. W pierwszej kolejności należałoby ocenić, czy atak na Wieluń był przykładem bombardowania taktycznego (tj. w strefie styczności bojowej - art. 24 ust. 4), czy też strategicznego (poza linią frontu - art. 24 ust. 3). Ujawnia się tutaj pierwsza wątpliwość interpretacyjna regulacji z $1923 \mathrm{r}$. Dokument nie przedstawia żadnych wytycznych, co należy uznawać za obszar „bezpośredniej bliskości działań lądowych". Z drugiej strony jasne było, że w strefie „styczności bojowej” lotnictwo posiada większy wachlarz działania, z uwagi na naturalne zwiększenie liczby celów wojskowych w postaci oddziałów

Routledge, 2019), 114-127, http://dx.doi.org/10.4324/9781351104449-11. Opis samego ataku, przygotowań do niego oraz skutków zob. Tadeusz Olejnik, Wieluń - polska Guernika (Kielce-Wieluń: Muzeum Ziemi Wieluńskiej, 2009).

83 Zob. Piątkowski, „Bombardowanie Wielunia. Bezsilność prawa międzynarodowego,” Gazeta Prawna.pl, wrzesień 2020, dostęp wrzesień 21, 2021, https://kultura.gazetaprawna. pl/artykuly/1489674,bombardowanie-wielunia-bezsilnosc-prawa-miedzynarodowego.html, komentarze-najstarsze; Piątkowski, „Bombardowanie Wielunia przypadło na czasy tzw. legalnego bezprawia," Obserwator międzynarodowy.pl, dostęp wrzesień 21, 2021, http://obserwator miedzynarodowy.pl/2019/09/01/dr-mateusz-piatkowski-bombardowanie-wielunia-przypadlo -na-czasy-legalnego-bezprawia-analiza/.

${ }^{84}$ Ze wspomnień Wacława Króla wynika, że latem 1939 r. w okolicach Wielunia 2 Pułk Lotniczy z Krakowa organizował tzw. zasadzkę - czyli doraźnie organizowane lądowisko dla 2-3 maszyn myśliwskich, których zadaniem było natychmiastowe reagowanie na przelot nieprzyjaciela w okolicach lądowiska na podstawie obserwacji wzrokowej. Wacław Król, Krakowskie skrzydła, Żółty Tygrys nr 4 (Warszawa: Wyd. Ministerstwa Obrony Narodowej, 1974), 8-9. 
przeciwnika. Zauważyć należy, że dokument był tworzony zaraz po zakończeniu I wojny światowej, gdy dominowała wojna pozycyjna i front można było określić geograficznie $\mathrm{z}$ dużą łatwością. W erze tzw. wojny manewrowej (niem. Blitzkrieg) ruchy jednostek pancerno-motorowych powodowały ciągłą zmianę sytuacji operacyjnej. ${ }^{85}$ Pomocniczym kryterium w tej mierze może być np. określenie donośności artylerii lądowej. Działa Wehrmachtu na szczeblu dywizyjnym były w stanie razić cele oddalone o ok. $10-13 \mathrm{~km}$, natomiast na szczeblu korpusu nawet do ok. $25 \mathrm{~km} .{ }^{86}$ $\mathrm{Na}$ przedpolach miasta 1 września 1939 r. trwały zaciekłe walki heroicznie broniącego się $36 \mathrm{pp}$. Jednakże nie sposób w tym miejscu analizy nie podkreślić wagi daty i godziny ataku na miasto, które zostało zbombardowane w chwili, w której front de facto nie istniał. Pomijając powyższe, $\mathrm{w}$ kontekście taktycznym usprawiedliwieniem ataku mogłoby być istnienie „koncentracji wojskowej”, która w Wieluniu nie miała miejsca. Nawet jeżeli pierwszy atak odbywał się w warunkach usprawiedliwionego błędu co do możliwej obecności jednostek wojskowych, to z pewnością okoliczność ta była już znana niemieckiemu dowództwu podczas drugiego (ok. godz. 6:00) i trzeciego (ok. godz. 14:00) nalotu. ${ }^{87}$

W kontekście strategicznym wskazywano na konieczność kierowania ataku ściśle przeciwko „celom wojskowym” wskazanym w art. 24 ust. 2 reguł z 1923 r. Oczywistych obiektów o przeznaczeniu militarnym w Wieluniu nie było. Brakowało jednostek wojskowych stacjonujących w mieście, nie istniały instalacje militarne i przemysłowe działające na potrzeby przemysłu obronnego. W tym kontekście należy jednakże wskazać na dodatkową kategorię celów w postaci szlaków komunikacyjnych oraz transportowych wykorzystywanych w celach wojskowych. Należy zaznaczyć, że wciąż w świetle art. 24 ust. 1 reguł z 1923 r. strona atakująca powinna wykazać, że zniszczenie celu wojskowego przynosi „wyraźną korzyść wojskową”. Ujawnia się w tej mierze, krytykowana słusznie przez doktrynę prawa międzynarodowego okresu międzywojennego, słabość haskich reguł wojny powietrznej, poprzez niedostateczne dookreślenie tego pojęcia, przy jednoczesnym tworzeniu enumeratywnego katalogu celów wojskowych. ${ }^{88}$ Jest ona dostrze-

85 Np. podczas operacji „Barbarossa” latem 1941 r. niektóre niemieckie dywizje pancerne były w stanie dziennie pokonywać dystanse rzędu ok. 80-90 km. Christopher Alisby, Piekło na froncie wschodnim, tłum. Maciej Antosiewicz (Warszawa: Wyd. Amber, 2001), 37.

86 Haubica leFH $10.5 \mathrm{~cm}$, haubice sFH $18115 \mathrm{~cm}$ oraz K18.

87 Zob. meldunek Waltera Siegla z $76 \mathrm{StG}$, informujący o „braku zaobserwowaniu jednostek wroga" podczas nalotu (niem. Keine besondere Feindbeobachtung). Przedruk w: Jan Książek, „Cel zniszczony... Z Dzienników wojennych Waltera Siegla i Kurta Hartmanna," Siódma Prowincja Kwartalnik Kulturalny, nr 3/4 (2005): 45. Abramowicz, „Tragedia,” 128.

88

Quindry, „Aerial,” 489-490. 
galna także w kontekście oceny Wielunia (a mówiąc bardziej precyzyjnie, jego układu komunikacyjnego) jako skrzyżowania dróg w regionie. Reguły nie dają pewnej odpowiedzi w tej mierze - czy m.in. dopuszczalne byłoby atakowanie miejscowości położonych $\mathrm{w}$ pobliżu frontu $\mathrm{z}$ uwagi na ich potencjalne wykorzystanie dla celów logistyki wojskowej: dostarczania zaopatrzenia, przerzucenia rezerw czy też dróg odwrotowych. Nawet w przypadku odpowiedzi twierdzącej reguły zakazywały w takich okolicznościach nalotu o charakterze strefowym, wymuszając większą selektywność na stronie atakującej, zezwalając na powstanie jedynie wąskiego zakresu zniszczeń.

Niemniej z perspektywy doświadczeń II wojny światowej należy dostrzec, że traktowanie całych miejscowości jako celów wojskowych z przyczyn „komunikacyjnych” - nawet gdy nie było one jeszcze wykorzystywane przez nieprzyjaciela - miało uzasadnienie w praktyce państw. ${ }^{89}$ Przykładem takiego działania są dokonywane wiosną 1944 r. naloty lotnictwa alianckiego na francuskie miejscowości położone w Normandii, celem sparaliżowania potencjalnych ruchów rezerw niemieckich drogą kolejową w okresie operacji „Overlord”, które doprowadziły do zniszczenia całych miejscowości i znacznych strat wśród ludności. ${ }^{90}$ Zdaniem Anthony'ego Gaughana ataki były naruszeniem zakazu saturacyjnego atakowania obszarów położonych poza linią frontu, a także przykładem wadliwej klasyfikacji jako celu wojskowego dróg kolejowych, które nie były jeszcze w chwili nalotu wykorzystywane przez stronę niemiecką. Nie można jednakże zaprzeczyć, że atakowanie miejscowości położonych na zapleczu planowanego desantu sprzymierzonych mogło efektywnie zaburzyć zdolności strony niemieckiej do przerzucenia rezerw. ${ }^{91}$ Ponadto, można odnaleźć więcej przykładów takich działań, jak np. uzasadnienie nalotów na Drezno w lutym 1945 r., które miały zatrzymać transporty rezerw niemieckich na front wschodni. ${ }^{92}$ Podobne działania podjęto także w ramach operacji „Strangle” we Włoszech

\footnotetext{
89 „The actual historical facts indicate, however unpleasant the contemption of this may be, that considerable ancillary civilian destruction has been tolerated in the application of the test providing that the target is a lawful military objective”; William T. Mallision, „Studies in the Law of Naval Warfare: Submarines in General and Limited Wars," International Law Studies 58, (1966): 177.
}

90 Działania lotnicze w tym obszarze były wynikiem tzw. „planu transportowego” zakładającego zniszczenie infrastruktury kolejowo-drogowej w północnej Francji, zob. Eduard Mark, Aerial Interdiction: Air Power and the Land Battle in Three American Wars (Washington: Center for Air Force History, 1994), 221-228.

91 Anthony Gaughan, D-Day, Collateral Damage, and the 1923 Hague Draft Rules of Aerial Warfare (Draft Paper Contingency in the Course of International Law Conference Amsterdam Center for International Law The University of Amsterdam June 16, 2018).

92 Joan M. Thomas, Jon I. Agirre i Ramon A. Mata, Bombs over Biscay, Barcelona and Dresden (1937-1945): From the Spanish Civil War to the Second World War (Tarragona: Publicacions URV, 2019), 80. 
w pierwszej połowie $1944 \mathrm{r}^{93}$ Zaklasyfikowanie układu komunikacyjnego jako celu nalotu w kontekście obszarów zabudowanych, mając na względzie realia techniczne lotnictwa bombowego w okresie II wojny światowej, niemal zawsze skutkowało rozległymi zniszczeniami. Powyższe uwagi korespondują $\mathrm{z}$ wnioskiem dotyczącym przyjęcia (zwłaszcza $\mathrm{w}$ drugiej fazie II wojny światowej) znacząco rozszerzonego konceptu „celu wojskowego". ${ }^{44}$

Wracając do kontekstu Wielunia, należy uznać za wysoce kontrowersyjne stwierdzenie, że wieluński węzeł komunikacyjny miał potencjalnie na tyle strategiczne znaczenie, aby osiągnąć wystarczający oraz konkretny poziom korzyści wojskowej usprawiedliwiający wielkie straty dla niewalczących. Sam obszar Wielunia w planach polskich i niemieckich nie miał dużego znaczenia militarnego. Miasto znajdowało się poza linią głównego oporu A „Łódź”, zlokalizowaną na linii Warty i Widawki, od Sieradza do Piotrkowa Trybunalskiego. Plany niemieckie zaś zakładały wyprowadzenie jednego potężnego uderzenia głównymi związkami motorowymi na Piotrków Trybunalski (10 A) oraz pomocniczego ataku na Sieradz (8 A). ${ }^{95}$ Nawet przy przyjęciu bardzo szerokiej definicji celu wojskowego (korzyść wojskowa w postaci zniszczenia miasta jako całości celem zniszczenia szlaków komunikacyjnych i sparaliżowania obrony pasa nadgranicznego, głównie 36 pp) nie uzasadniało rozległego i systematycznego niszczenia miasta wielokrotnymi nalotami. Wiele przemawia za rozmyślnym atakiem na ludność cywilną, ze zbrodniczym zamysłem w postaci:

- przeprowadzenia drugiego i trzeciego ataku, w warunkach wiedzy o braku obecności jednostek Wojska Polskiego w mieście;

- wydania rozkazu do startu samolotów do pierwszego ataku bez oczekiwania na wyniki rozpoznania obszaru Wielunia ok. godz. 4:00 w dniu 1 września 1939 r.;

- użycia charakterystycznej metody nalotu mającej na celu spowodowanie jak największych zniszczeń wśród zabudowy miejskiej, a mianowicie bomb burzących, które w pierwszej kolejności miały uszkodzić instalacje przeciwpożarowe oraz zapalających, mających na celu wywołanie pożarów. Powyższe modus operandi miało zastosowanie w przypadku innych ataków prowadzonych przez jednostki lotnicze dowodzone przez

93 Operacja miała na celu zniszczenie dróg transportu kolejowego i kołowego, wspierających niemieckie pozycje na tzw. linii Gustawa. Szczególnie dotknięta przebiegiem bombardowań lotniczych była Bolonia, w której blisko 50\% zabudowy miejskiej uległo zniszczeniu.

94 DeSaussure, „The Laws," 284.

95 Włodzimierz Kozłowski, „Wojskowe znaczenie Ziemi Łódzkiej w 1939 r.”, Acta Universitatis Lodziensis, Folia Historica 8, (1981): 104; Boje polskie 1939-1945: Przewodnik Encyklopedyczny, red. Krzysztof Komorowski (Warszawa: Bellona, 2009), 51-53. 
Wolframa von Richthofena i Alexandra Lohra odpowiednio w Guernice oraz Belgradzie; ${ }^{96}$

- użycie samolotów zdolnych do precyzyjnego uderzenia w sposób charakterystyczny dla bombowców horyzontalnych. Bombowiec nurkujący Ju-87B Stuka wypełniał przewidzianą w Blitzkriegu rolę ,artylerii powietrznej”, mając $\mathrm{w}$ pierwszej kolejności wykonywać zadania na korzyść wojsk lądowych. W tych działaniach ważniejsza od siły ognia była dokładność, którą oferował Stuka dzięki możliwości zrzucenia bomby z wysokości ok. $500 \mathrm{~m}$ nad celem z lotu nurkowego mogącego osiągnąć nawet 90 stopni. ${ }^{97}$

Kolejne zawiłości wynikają z przepisów międzynarodowego prawa karnego. Zgodnie z tzw. zasadą Rendulica (konstrukcja będąca odpowiednikiem tzw. błędu co do faktu) niedopuszczalne jest ocenianie podejmowanych działań bojowych $\mathrm{w}$ wymiarze post factum. ${ }^{98}$ MTW określił w orzeczeniu o standardzie „rozsądnego dowódcy”, który podejmuje decyzje na podstawie przesłanek i okoliczności znanych w momencie procesu decyzyjnego. ${ }^{99}$ Obejmuje to możliwość popełnienia rozsądnych i uzasadnionych błędów, lecz nie może prowadzić do aprobaty ignorancji ze strony dowodzącego. ${ }^{100} \mathrm{~W}$ literaturze podnosi

96 „Wieluń, polska Guernica. Oba miasta zaatakował ten sam zbrodniarz,” Deutsche Welle, dostęp wrzesień 21, 2021, https://www.dw.com/pl/wieluń-polska-guernica-oba-miastazaatakował-ten-sam-zbrodniarz/a-50330625. Atak na Belgrad w ramach operacji „Odwet” (niem. Strafgericht) w dn. 6 IV 1941 r. jest przykładem innego nalotu o wielce kontrowersyjnym charakterze. Podobnie jak Wieluń, stolica ówczesnej Jugosławii została zaatakowana w ramach tzw. pierwszego ataku w godzinach rannych przez ok. 200-300 samolotów, w tym Ju-87 Stuka. Użyto wówczas bomb zapalających i burzących. Atak ten dokonał rozległych zniszczeń i przyniósł śmierć ok. 17 tys. osób. Istnieją kontrowersje, czy przedmiotem uderzenia były cele wojskowe rozmieszczone w centrum miasta, czy też nalot celowo przeprowadzono w sposób rozległy, aby spowodować jak największe straty wśród ludności cywilnej. W przeciwieństwie do Wielunia Belgrad był jednak stolicą państwa, z oczywistym nasyceniem celów wojskowych, był także broniony przez lotnictwo Jugosławii i artylerię przeciwlotniczą. O nalocie na Guernikę zob. Antony Beevor, Walka o Hiszpanię 1936-1939: Pierwsze starcie totalitaryzmów, tłum. Hanna Szczerkowska (Kraków: Społeczny Instytut Znak, 2009), 320-322.

97 Tuż przed bombardowaniem Wielunia, na poligonie w Neuhammerm 15 VIII $1939 \mathrm{r}$. podczas treningowego lotu nurkowego, dowodzona przez Waltera Siegela (z 76 StG) eskadra rozbiła się $\mathrm{w}$ wyniku zderzenia $\mathrm{z}$ ziemią $\mathrm{z}$ powodu zbyt późnego wyprowadzenia samolotów z nurkowania. Formą „rehabilitacji” dowódcy było zaproponowanie mu przeprowadzenia akcji na Wieluń. Zob. John Ward, Hitler's Stuka Squadrons: The JU 87 at War 1936-1945 (Londyn: Spellmount, 2004), 57-58.

98 Piątkowski, „The Rendulic Rule and the Law of Aerial Warfare," Polish Review of International and European Law 2, (2013): 72-74.

$99 \quad$ Law Reports of Trials of War Criminals: Selected and Prepared by The United Nations War Crimes Commission, t. 8, The Hostage Trial, Trial of Wilhelm List and Others (London: The United Nations War Crime Commision by His Majesty's Stationery Office, 1949), 68-69.

100 Report of the International Law Commission on the work of its forty-eighth session, 6 May - 26 July 1996, Official Records of the General Assembly, Fifty-first session, Supplement No. 10, 41 . 
się, że uzasadnieniem ataków mogłoby być przekonanie niemieckiego wywiadu o obecności brygady kawalerii w mieście. ${ }^{101} \mathrm{~W}$ świetle przytoczonych wyżej okoliczności wydaje się to mało prawdopodobne, lecz dokładne ustalenie tej okoliczności wymagałoby zbadania niemieckich map sztabowych (co jest zamiarem badawczym autora). Warto wspomnieć, że okoliczność ta może dotyczyć jedynie pierwszego nalotu. W kontekście standardu „rozsądnego dowódcy" wielce problematyczna wydaje się również kwestia wysłania na miasto dwóch samolotów rozpoznawczych typu Dornier Do-17, które nie były w stanie odnaleźć miasta. Jeżeli celem tych misji miało być potwierdzenie informacji o koncentracji wojskowej w Wieluniu, to decyzja o starcie była podjęta ze świadomością, że cel nie został rozpoznany co do swojego charakteru. ${ }^{102}$

W ocenie autora artykułu bombardowanie Wielunia ma szczególne miejsce $\mathrm{w}$ historii prawa wojny powietrznej. Wynika to $\mathrm{w}$ pierwszej kolejności z ustalenia czasu rozpoczęcia działań. Nawet jeżeli przyjąć godzinę późniejszą niż 4:40, to nalot był bez wątpienia pierwszym aktem II wojny światowej, jeżeli nie w ujęciu ogólnopolskim, to przynajmniej regionalnym. Celem tego swoistego "napadu powietrznego" było pogrążone w śnie miasto, funkcjonujące wciąż w realiach pokoju, nie wojny, w którym nie znajdowały się wyraźne cele wojskowe. Te fakty wyraźnie oddzielają ocenę ataku na Wieluń od wszystkich innych aktów powietrznych okresu II wojny światowej i mogą być podstawą przyjęcia, że niewielkie przygraniczne miasto było faktycznie „miastem niebronionym” w rozumieniu art. 25 regulaminu haskiego z 1907 r., także w kontekście wojny powietrznej.

\section{Cień Norymbergi}

$\mathrm{Na}$ ocenę ataku lotniczego na Wieluń jako zbrodni wojennej wielkim cieniem kładzie się dziedzictwo (a raczej jego brak) trybunału norymberskiego. Nie ma wątpliwości, że zagadnienie bombardowań powietrznych stało się z punktu widzenia prawnego i politycznego najbardziej kontrowersyjnym elementem przyszłego procesu karnego przeciwko zbrodniarzom wojennym. Należy zauważyć, że argument tu quoque podniesiony przez oskarżonych w procesie Einsatzgruppe, którzy wskazywali na fakt

\footnotetext{
101 Podobne rozważania pojawiają się także w literaturze zachodniej: „Along with other units, von Richthofen's I./StG 77 decimated a Polish Cavalry Brigade of Armii Łódź during the Battle of Łódź”, cyt. za: Gustavo Urena, „Generalfeldmarshall Wolfram Freiherr von Richthofen," dostęp wrzesień 21, 2021: https://www.academia.edu/33975006/Generalfeldmarshall_Wolfram_Freiherr_von_Richthofen.

102 Stanisław Abramowicz, „Tragedia Wielunia w świetle materiałów śledztwa Oddziałowej Komisji Ścigania Zbrodni Przeciwko Narodowi Polskiemu," w Wieluń był pierwszy: Bombardowania lotnicze miast regionu łódzkiego we wrześniu 1939 r., red. Janusz Wróbel (Łódź: Instytut Pamięci Narodowej, 2009), 119.
} 
popełnienia przez aliantów zbrodni poprzez naloty wykonywane w ramach połączonej ofensywy bombowej (Combined Bomber Offensive), mógł doprowadzić do podważenia legitymacji międzynarodowej trybunału. ${ }^{103}$ Mowa tu o okolicznościach związanych z nalotami na Hamburg, Berlin, Drezno, a także atakach $\mathrm{z}$ użyciem bomb atomowych na Tokio i Hiroszimę.

Pojawia się jednakże w tym miejscu zagadnienie natury materialnoprawnej. Stypizowane na gruncie art. 6 ust. b karty londyńskiej MTW znamiona zbrodni wojennej stanowią o „bezmyślnym niszczeniu miast, wsi oraz osad nieusprawiedliwionego koniecznością wojskową". ${ }^{104}$ Prima facie dyspozycja przepisu powinna obejmować również czyny popełnione w związku z bombardowaniami powietrznymi. Jednak ani przebieg prac przygotowawczych trybunału norymberskiego, ani treść aktów oskarżenia i innych działań podjętych $\mathrm{w}$ ramach właściwych procesów nie popiera powyższego poglądu. ${ }^{105}$ Zarzuty formułowane w oparciu o art. 6 ust. b karty londyńskiej MTW dotyczyły tylko i wyłącznie naruszeń obowiązków strony okupującej, określonych na gruncie art. 46 i 50 regulaminu haskiego z 1907 r. ${ }^{106} \mathrm{Z}$ uwagi na powyższe art. 6 MTW może nie stanowić podstawy materialnoprawnej zbrodni wojennej polegającej na bombardowaniu miejscowości niebronionej. ${ }^{107} \mathrm{Czyn}$ w postaci „umyślnego bombardowania niebronionych obszarów” został wymieniony w katalogu zbrodni wojennych przygotowanym przez raport Komisji ds. Odpowiedzialności Autorów Wojny po zakończeniu I wojny światowej (Commission on the Responsibility of the Authors of the War and on Enforcement of Penalties). ${ }^{108} \mathrm{~W}$ czasie II wojny światowej Japonia przyjęła specjalne ustawy, które przewidywały odpowiedzialność karną alianckich lotników dokonujących nalotów bez rozróżnienia, jednakże nie oceniono ich zgodności $\mathrm{z}$ prawem międzynarodowym. ${ }^{109}$ Podobne sformułowanie, penalizujące akty bombardowań powietrznych sprzeczne $\mathrm{z}$ prawem międzynarodowym, nie

103 Trials of War Criminals Before the Nuremberg Military Tribunals, t. 4, „The Einsatzgruppen Case" (Washington: United States Government Printing Office, 1950), 379.

104 Porozumienie międzynarodowe w przedmiocie ścigania i karania głównych przestępców wojennych Osi Europejskiej, Londyn, 8 VIII 1945 r. (Dz. U. 1947, nr 63, poz. 367).

105 Mallison, „Studies, 179-180. „United Nations War Crimes Commission, Deliberate Bombardment of Undefended Places, Report by Committee III, C.250, Legal Tools," dostęp październik 27, 2021, https://www.legal-tools.org/doc/9b9ca9/.

106 Zarzuty w oparciu o naruszenie art. 6(b) karty londyńskiej MTW sformułowano w odniesieniu m.in. do akcji pacyfikacyjnych podjętych na terenie b. Jugosławii, Grecji oraz Czechosłowacji.

107 Anthony C. Grayling, Among the Dead Cities: Is The Targeting of Civilians $n$ War Ever Justified (London: Bloomsbury, 2006), 212.

108 "Commission on the Responsibility of the Authors of the War and on Enforcement of Penalties," The American Journal of International Law 14, (1920): 115.

109 DeSaussure, „International Law and Aerial Bombing," The United States Air Force Air University Quarterly Review 5, (1952): 30. 
znalazło się w treści karty londyńskiej MTW. Zwrócono uwagę na powyższy fakt w raporcie Komisji Zbrodni Wojennych Narodów Zjednoczonych, w którym uznano, że zbrodnia „umyślnego bombardowania niebronionych obszarów" nie stanowi zbrodni w świetle prawa międzynarodowego. ${ }^{110} \mathrm{Co}$ znamienne, raport ten był odpowiedzią na zapytanie Podkomisji dla $\mathrm{Da}$ lekiego Wschodu, żądającej sprecyzowania stanowiska prawnego w przedmiocie bombardowań lotniczych, dokonanych przez lotnictwo japońskie podczas wojny w Chinach. ${ }^{111} \mathrm{~W}$ podsumowaniu stwierdzono wręcz, że sformułowanie „miejscowości niebronione” należy wprost rozumieć jako „miejscowości, w obrębie których nie znajdują się cele wojskowe". ${ }^{112}$

Obecnie zbrodnia wojenna polegająca na atakowaniu „niebronionych miejscowości" została przeformułowana w ramach art. 8 ust. 2 lit. b ppkt $\mathrm{V}$ statutu rzymskiego MTK. ${ }^{113} \mathrm{~W}$ treści przepisu zaznaczono, że oprócz spełnienia kryterium „bezbronności” dane miasto, wieś lub dom mieszkalny nie może być jednocześnie celem wojskowym. ${ }^{114}$

\section{Podsumowanie}

Jak przed laty wskazał Bierzanek, prawo wojny powietrznej jest jednym z niewielu segmentów prawa międzynarodowego, który jest tak niewspółmiernie nieadekwatny do znaczenia materii będącej przedmiotem

110 „United Nations War Crimes Commission, Deliberate Bombardment of Undefended Places, Preliminary Report by Egon Schwelb, Legal Officer, III/78, Legal Tools,” dostęp październik 27, 2021, https://www.legal-tools.org/doc/9b9ca9/pdf/.

111 „United Nations War Crimes Commission, Committee III, Request from the Far Eastern and Pacific Sub-Commission concerning the war crime of deliberate bombardment of undefended places, III/77. Legal Tools," dostęp październik 27, 2021, https://www.legal-tools.org/doc/ce66b1/pdf/.

112 „United Nations War Crimes Commission, Deliberate Bombardment of Undefended Places, Draft Report by Committee II, summarizing Documents III/78 and I/82 and embodying the results of the discussion in Committee III meeting of 26th February, 1947 (III/79), Legal Tools," dostęp październik 27, 2021, https://www.legal-tools.org/doc/b0030f/.

113 „[...] atakowanie lub bombardowanie, przy użyciu jakichkolwiek środków, bezbronnych miast, wsi, domów mieszkalnych i budowli niebędących celami wojskowymi”. Rzymski statut Międzynarodowego Trybunału Karnego sporządzony w Rzymie dnia 17 VII 1998 r. (Dz. U. 2003, nr 78, poz. 708).

114 Analiza prac przygotowawczych wskazuje na wątpliwości delegatów co do utrzymania w ramach statutu MTK oryginalnego, niemal niezmienionego kształtu przepisu zapożyczonego wprost $\mathrm{z}$ art. 25 regulaminu haskiego z 1907 r. Jako kompromis przyjęto wymóg, aby jednocześnie przedmiot ataku „nie był celem wojskowym”. Wątpliwości budzi jednakże pkt 2 elementów zbrodni art. 8(2)(b)(v), który wymaga, aby dany obszar zabudowany „był otwarty dla okupacji, bez stawiania oporu”, który ponownie odnosi się jedynie do czynnika lądowego, a nie powietrznego bądź morskiego. Knut Dormann, Elements of War Crimes under the Rome Statute of the International Criminal Court: Sources and Commentary (Cambridge: Cambridge University Press, 2003), 179. 
regulacji. ${ }^{115}$ Podstawą powyższego twierdzenia jest bez wątpienia doświadczenie II wojny światowej. Nieliczne, rozrzucone normy o naturze traktatowo-zwyczajowej, w dodatku w wielu wypadkach obarczone istotnymi wadami (jak np. art. 25 regulaminu haskiego z 1907 r.), sprzyjały powstaniu równoważnych modeli interpretacyjnych reżimu bombardowań powietrznych. W ujęciu skrajnym - jak stwierdził głównodowodzący sił bombowych Królewskich Sił Powietrznych (Royal Air Force Bomber Command) marszałek lotnictwa Arthur Harris - „prawo międzynarodowe nie regulowało użycia lotnictwa w czasach wojny". 116 Inna wykładnia bazowała na otwartej teorii celu wojskowego, $\mathrm{w}$ ramach której przedmiotem ataku powietrznego mogą być, oprócz obiektów „Z natury” uznanych jako wojskowe, cele ekonomiczne i infrastrukturalne, niezależnie od miejsca ich położenia i umiejscowienia względem ludności i dóbr cywilnych. Teoria restrykcyjna, stosowana przez aliantów w pierwszym okresie wojny (do 1942 r.), ma pewną podbudowę normatywną, bazującą na przekonaniu o wiążącym charakterze haskich reguł wojny powietrznej z 1923 r., nakazującą ograniczenie działań powietrznych jedynie do atakowania celów wojskowych „w ścisłym tego słowa znaczeniu”. Jednak jej obowiązywanie „załamało się” w świetle przeciwstawnej praktyki wszystkich uczestników konfliktu. Zaważyło to bezpośrednio na postępowaniu trybunałów: norymberskiego i tokijskiego, które nie odniosły się w żaden sposób do prawnych aspektów bombardowań powietrznych w okresie II wojny światowej. Atak na Wieluń pierwszego dnia tego konfliktu zajmuje szczególne miejsce w świetle prawa bombardowań powietrznych. Okoliczności towarzyszące tej akcji uzasadniają odmienną kwalifikację prawną, być może wyjątkową w odniesieniu do całego konfliktu. „Milczenie” trybunałów karnych powołanych po 1945 r. miało poważne konsekwencje w przyszłości, gdyż do 1977 r. wojna powietrzna była nieuregulowana żadnymi wyraźnymi normami prawa pozytywnego.

\section{Bibliografia}

\section{Akty prawne}

Declaration (IV,1), to Prohibit, for the Term of Five Years, the Launching of Projectiles and Explosives from Balloons, and Other Methods of Similar Nature. The Hague, 29 July 1899. Dostęp wrzesień 19, 2021. https://ihl-databases.icrc.org/ihl/ INTRO/160?OpenDocument.

Konwencja dotycząca praw i zwyczajów wojny lądowej (Dz. U. 1927, nr 21, poz. 161).

115 Bierzanek, Wojna, 299.

116 Cyt.za: Meyer, „Tearing,” 146. 
Konwencja (IV) dotycząca praw i zwyczajów wojny lądowej wraz z regulaminem dotyczącym praw i zwyczajów wojny lądowej. (Dz. U. 1927, nr 21, poz. 161).

Konwencja genewska o polepszeniu losu chorych i rannych w armjach czynnych, podpisana dnia 27 lipca 1929 r. (Dz. U. 1932, nr 103, poz. 864).

Oświadczenie rządowe z dnia 28 listopada 1935 r. w sprawie przystąpienia Polski i szeregu państw do konwencji o bombardowaniu przez morskie siły zbrojne w czasie wojny z dnia 18 października 1907 r., oraz jej ratyfikacji (Dz. U. 1936, nr 6, poz. 66).

Porozumienie międzynarodowe w przedmiocie ścigania i karania głównych przestępców wojennych Osi Europejskiej, Londyn, dnia 8 sierpnia 1945 r. (Dz. U. 1947, nr 63, poz. 367).

Protokół dodatkowy do konwencji genewskich z dnia 12 sierpnia 1949 r., dotyczący ochrony ofiar międzynarodowych konfliktów zbrojnych Genewa, dnia 8 czerwca 1977 r. (Dz. U. z 1992, nr 41, poz. 175, załącznik).

Protokół dotyczący zakazu używania na wojnie gazów duszących, trujących lub podobnych oraz środków bakteriologicznych (Dz. U. 1929, nr 28, poz. 278).

Rzymski statut Międzynarodowego Trybunału Karnego sporządzony w Rzymie dnia 17 lipca 1998 r. (Dz. U. 2003, nr 78, poz. 708).

Statut Międzynarodowego Trybunału Sprawiedliwości (Dz. U. 1947, nr 23, poz. 90).

\section{Orzeczenia}

„Orzeczenie Stałego Trybunału Arbitrażowego z 4 IV 1928 r." Island of Palmas Case (Netherlands, USA), Recueil Des Sentences Arbitrales. T. 2. United Nations: 2006.

Law Reports of Trials of War Criminals: Selected and Prepared by The United Nations War Crimes Commission. T. 10, The I.G. Farben and Krupp Trials. London: The United Nations War Crimes Commission By His Majesty's Stationery Office, 1949.

Law Reports of Trials of War Criminals: Selected and Prepared by The United Nations War Crimes Commission. T. 8, The Hostage Trial, Trial of Wilhelm List and Others. London: The United Nations War Crime Commision by His Majesty's Stationery Office, 1949.

Trial of The Major War Criminals Before the International Military Tribunal, Nuremberg 14 November 1945 - 1 October 1946. Nuremberg 1947: International Military Tribunal.

Trials of War Criminals Before the Nuremberg Military Tribunals. T. 4, „The Einsatzgruppen Case”. Washington: United States Government Printing Office, 1950.

Trials of War Criminals Before the Nuremberg Military Tribunals. T. 6, „The Flick Case". Washington: United States Government Printing Office, 1952.

„Wyrok Sądu Okręgowego w Tokio z 7.12.1963 r.” Dostęp wrzesień 21, 2021. https://ihl -databases.icrc.org/applic/ihl/ihl-nat.nsf/0/aa559087dbcf1af5c1256a1c0029f14d.

\section{Podręczniki}

International Law - The Conduct of Armed Conflict and Air Operations (110-31). Washington: US Air Force, 1976.

Rules of Land Warfare FM 27-10. Washington: United States Government Printing Office, 1947.

United States Department of the Army. International Law. T. 2. Washington: Department of the Army, 1962. 


\section{Opracowania}

Abramowicz, Stanisław. „Tragedia Wielunia w świetle materiałów śledztwa Oddziałowej Komisji Ścigania Zbrodni Przeciwko Narodowi Polskiemu." W Wieluń byt pierwszy: Bombardowania lotnicze miast regionu łódzkiego we wrześniu 1939 r. Red. Janusz Wróbel, 103-143. Łódź: Instytut Pamięci Narodowej, 2009.

Alisby, Christopher. Piekło na froncie wschodnim. Tłum. Maciej Antosiewicz. Warszawa: Wyd. Amber, 2001.

Bechoff. Roland. „Laviation et les lois de la guerre." Revue générale de droit aérien 1, (1932): 526-538.

Beevor, Anthony. Walka o Hiszpanię 1936-1939: Pierwsze starcie totalitaryzmów. Tłum. Hanna Szczerkowska. Kraków: Społeczny Instytut Znak, 2009.

Bierzanek, Remigiusz. „1923 Hague Rules: Commentary.” W The Law of Naval Warfare: A Collection for Agreements and Documents with Commentarie. Red. Natalino Ronzitti, 396-409. Haga: Brill, 1988.

Bierzanek, Remigiusz. Wojna a prawo międzynarodowe. Warszawa: Wyd. Ministerstwa Obrony Narodowej, 1982.

Brown, Bernard. „The Proportionality Principle in the Humanitarian Law of Warfare: Recent Efforts at Codification." Cornell International Law Journal 10, (1976): 134-155.

Carnahan, Bruce M. „The Law of Air Bombardment in Its Historical Context.” The Air Force Law Review 17, nr 2 (1975): 39-60.

Colby, Eldridge. „Laws of Aerial Warfare” Minnesota Law Review 10, (1925-1925): 309-324.

Corwin, David. „The Legality of Nuclear Arms Under International Law.” Penn State International Law Review 5, nr 2 (1987): 271-291.

Cybichowski, Zygmunt. Międzynarodowe prawo wojenne: Z uwzględnieniem przesilenia bałkańskiego. Lwów: Gubrynowicz i Syn, 1914.

D’Amaoto, Anthony. International Law and Political Reality: Collected Papers Volume One. Haga: Martinus Nijhoff Publishers, 1995.

DeSaussure, Hamilton. „International Law and Aerial Bombing.” The United States Air Force Air University Quarterly Review 5, (1952): 22-34.

DeSaussure, Hamilton. „The Laws of Air Wafare: Are There Any?” International Law Studies 62, nr 1 (1977): 280-291.

Dinstein, Yoram. „Air Warfare.” W The Law of Armed Conflict and the Use of Force: The Max Planck Encyclopedia of Public International Law: Thematic Series Volume 2. Red. Frauke Lauchenman i Ruediger Wolfrum, 13-26. Oxford: Oxford University Press, 2017.

Dinstein, Yoram. „The Thirteenth Waldemar A. Solf Lecture in International Law.” Military Law Review 166, (2000): 93-108.

Dormann, Knut. Elements of War Crimes under the Rome Statute of the International Criminal Court: Sources and Commentary. Cambridge: Cambridge University Press, 2003.

Dunworth, Teresa. Humanitarian Disarmament: An Historical Enquiry. Cambridge: Cambridge University Press, 2010.

Fenrick, William J. „Applying IHL Targeting Rules To Practical Situations: Proportionality and Military Objectives." Windsor Yearbook of Access to Justice 27, (2009): 271-283.

Fiszer, Michał. Lotnictwo w osiaganiu celów strategicznych operacji militarnych, Warszawa: Trio, 2011. 
Fleck, Dieter. „Strategic Bombing and the Definition of Military Objectives.” Israel Yearbook on Human Rights 27, (1997): 41-64.

Ford, John. „The Morality of Obliteration Bombing.” Theological Studies 5, nr 3 (1944): 261-309.

Gaughan, Anthony. D-Day, Collateral Damage, and the 1923 Hague Draft Rules of Aerial Warfare. Draft Paper Contingency in the Course of International Law Conference Amsterdam Center for International Law The University of Amsterdam, June 16, 2018.

Goda, Paul J. „The Protection of Civilians from Bombardment by Aircraft: The Ineffectiveness of the International Law of War." Military Law Review 33, nr 93 (1966): 93-113.

Grayling, Anthony C. Among the Dead Cities: Is The Targeting of Civilians $n$ War Ever Justified. London: Bloomsbury, 2006.

Green, Lessie C. Essays on the Modern Law of War. New York: Transnational Publishers, 1985.

Grey, Peter. Air Warfare: History, Theory and Practice. London: Bloomsbury, 2016.

Grzebyk, Patrycja. Cele osobowe i rzeczowe w konfliktach zbrojnych $w$ świetle prawa międzynarodowego. Warszawa: Scholar, 2018.

Hanke, Heinz Marcus. „The 1923 Hague Rules of Air Warfare: A Contribution To The Development of International Law Protecting Civilians From Air Attack." International Review of the Red Cross, nr 292, (1993): 12-44.

Henckearts, Jean Marie. Studium poświęcone zwyczajowemu międzynarodowemu prawu humanitarnemu: wkład $w$ zrozumienie i poszanowanie zasad prawa dotyczacych konfliktu zbrojnego. Tłum. Michał Sajkowski. Warszawa: Drukarnia Janusz Bieszczad, 2006.

Henderson, Ian. The Contemporary Law of Targeting. Leiden: Martinus Nijhoff Publishers, 2009.

Holman, Brett. The Next War in the Air: Britain's Fear of the Bomber, 1908-1941. Farnham: Ashgate Publishing Limited, 2014.

Hyde, Charles. International Law Chiefly as and Applied by the United States. Boston: Little, Brown, and Company, 1922.

Jachec-Neale, Agnieszka. The Concept of Military Objectives in International Law and Targeting. New York: Routledge, 2015.

Jochnick, Chris i Roger Normand. „The Legitimation of Violence: A Critical History of the Laws of War." Harvard International Law Journal 35, (1994): 49-96.

Komorowski, Krzysztof, red. Boje polskie 1939-1945: Przewodnik encyklopedyczny. Warszawa: Bellona, 2009.

Kozłowski, Włodzimierz. „Wojskowe znaczenie Ziemi Łódzkiej w 1939 r.” Acta Universitatis Lodziensis, Folia Historica, nr 8 (1981): 93-108.

Król, Wacław. Krakowskie skrzydła. Żółty Tygrys nr 4. Warszawa: Wyd. Ministerstwa Obrony Narodowej, 1974.

Książek, Jan. „Cel zniszczony... Z Dzienników wojennych Waltera Siegla i Kurta Hartmanna." Siódma Prowincja Kwartalnik Kulturalny, nr 3/4 (2005): 44-46.

Kunz, Josef. Kriegsrecht und Neutralitätsrecht. Berlin: Springer, 1935.

Lauterpacht, Hersch. The Function of Law in the International Community. New Jersey: The Lawbook Exchange, 2000.

Leroy, Howard S. „Limitation of Air Warfare.” Air Law Review 12, (1941): 19-33. 
Levine, Alan J. The Strategic Bombing of Germany 1940-1945. Westport: CT, 1992.

Mallison, W. Thomas. "Studies in the Law of Naval Warfare: Submarines in General and Limited Wars." International Law Studies 58, (1966): 1-28.

Mark, Eduard. Aerial Interdiction: Air Power and the Land Battle in Three American Wars. Washington: Center for Air Force History, 1994.

Marud, Wiesław. „Bombardowania lotnicze z perspektywy prawa międzynarodowego." Zeszyty Naukowe AON 81, (2010): 128-147.

McCosker, Sarah. „Domains of Warfare.” W The Oxford Guide to International Humanitarian Law. Red. Ben Saul i Dapo Akande, 77-99. Oxford: Oxford University Press, 2020.

Meron, Teodor. „The Martens Clause, Principles of Humanity and Dictates of Public Conscience." The American Journal of International Law 94, nr 1 (2000): 78-89.

Meyer, Jeanne. „Tearing Down the Facade: A Critical Look At The Current Law on Targeting The Will of The Enemy and Air Force Doctrine." The Air Force Law Review 51, (2001): 143-182.

Meyrowitz, Henri. „Le bombardernent strategique d'apres le Protocole additionnel I aux Conventions de Geneve." Zeitschrift für ausländisches öffentliches Recht und Völkerrecht 41, (1981): 1-68.

Moore, John B. International Law and Some Current Illusions: And Other Essays. New York: Macmillan, 1924.

Nault, Derrick M. Africa and the Shaping of International Human Rights. Oxford: Oxford University Press, 2020.

Nelson, Robert i Christopher Waters. „The Allied Bombing of German Cities during the Second World War from a Canadian Perspective." Journal of the History of International Law 14, (2012): 87-122.

Oeter, Stefan. „Means and Method of Warfare.” W The Handbook of International Humanitarian Law. Red. Dieter Fleck, 401-489. Oxford: Oxford University Press, 2013.

Parks, Hays William. „Air War and the Law of War.” Air Force Law Review 32, (1990): 1-226.

Parks Hays, William. „Perspective and the Importance of History”. Yearbook of International Humanitarian Law 14, (2011): 361-382.

Parks, Hays William. „The Protection of Civilians From Air Warfare.” Israel Yearbook on Human Rights 27, (1997): 65-112.

Pearce Higgins, Alexander. The Hague Peace Conferences and Other International Conferences Concerning The Laws and Usages of War: Texts of Conventions with Commentaries. Cambridge: Cambridge University Press, 1909.

Piątkowski, Mateusz. "Judging the past - international humanitarian law and the Luftwaffe aerial operations during the invasion of Poland in 1939." W International Humanitarian Law and Justice Historical and Sociological Perspectives. Red. Mats Deland, Mark Klamberg i Paul Wrange, 114-127. New York: Routledge, 2019. http://dx.doi.org/10.4324/9781351104449-11.

Piątkowski, Mateusz, „Prawo międzynarodowe konfliktów zbrojnych i działalność polskiego lotnictwa wojskowego we wrześniu 1939 roku w świetle wytycznych najwyższych władz wojskowych.” W Szkice z historii lotnictwa polskiego. T. 2, Udział Lotnictwa $w$ walce o niepodległość na frontach II wojny światowej oraz wybrane aspekty funkcjonowania współczesnych sił powietrznych. Red. Adam 
Radomyski, Krzysztof Ogonowski i Andrzej Olejko, 27-39. Dęblin: Wyższa Szkoła Oficerska Sił Powietrznych, 2017.

Piątkowski, Mateusz. „Przepisy IV Konwencji haskiej z 1907 r. w świetle wojny powietrznej." Polski Przegląd Stosunków Międzynarodowych 3, (2013): 126-127.

Piątkowski, Mateusz. „Security of the Civilian Population From the Consequences of Aerial Warfare in The Light of the Hague Rules of Aerial Warfare of 1923." W $3^{\text {rd }}$ International Conference of PhD Students and Young Researcher Security As a Purpose of Law. Red. Gintare Tamašauskaite-Janickè, 182-190. Vilinus: Vilinus University, 2016.

Piątkowski, Mateusz. „The Rendulic Rule and the Law of Aerial Warfare.” Polish Review of International and European Law 2, (2013): 69-85.

Piątkowski, Mateusz. „Wieluń - 1 IX 1939 r. Bombardowanie miasta a międzynarodowe prawo konfliktów zbrojnych.” Wojskowy Przegląd Prawniczy, nr 2 (2013): 21-53.

Piątkowski, Mateusz. Wojna powietrzna a międzynarodowe prawo humanitarne. Łódź: Wyd. Uniwersytetu Łódzkiego, 2021.

Quindry, Frank. „Aerial Bombardment of Civilian and Military Objectives.” Journal of Air Law and Commerce 2, (1931): 474-509.

Rabkin, Jeremy. „The Strange Pretenstions of Contemporary Humanitarian Law.” W Rethninking the Law of Armed Conflict in an Age of Terrorism. Red. Christopher Ford i Amichai Cohen, 41-71. Plymouth: Lexington Books, 2012.

Robertson, Horace B. „1907 Hague Convention IX Concerning Bombardment by Naval Forces in Time of War." W The Law of Naval Warfare: A Collection of Agreements and Documents with Commentaries. Red. Natalino Ronzitti, 161-173. Dordrecht: Martinus Nijhoff Publishers, 1988.

Robertson, Horace B. Jr. „The Status of Civil Aircraft in Armed Conflict.” Israel Yearbook on Human Rights 27, (1997): 113-150.

Ronzitti, Natalino. „The Codification of Law of Air Warfare.” W The Law of Air Warfare: Contemporary Issues. Red. Natalino Ronzitti i Gabriela Venturini, 3-17. Utrecht: Eleven International Publisher, 2006.

Rotocki, Zbigniew. „Polish Directives of 1939 Concerning Aerial Bombardment in the Light of International Rules of Air Warfare." Polish Yearbook of International Law 3, (1970): 143-169.

Schindler, Dieter i Jiri Toman. The Laws of Armed Conflicts: A Collection of Conventions, Resolutions and Other Documents. Dordrecht: Marinus Nijhoff Publishers, 1988.

Skubiszewski, Krzysztof. „Prawo wojny i neutralności w świecie współczesnym.” Ruch Prawniczy, Ekonomiczny i Socjologiczny, nr 1 (1967): 105-125.

Sołonin, Mark. 22 czerwca 1941 - czyli jak zaczęła się Wielka Wojna Ojczyźniana. Tłum. Tomasz Lisiecki. Poznań: Rebis, 2008.

Spetzler, Eberhard. Luftkrieg und Menschlichkeit. Die völkerrechtlich Stellung der Zivilpersonen im Luftkrieg. Berlin: Musterschmidt, 1956.

Terry, Jay. „The Evolving Law of Aerial Warfare.” Air University Review 37, nr 1 (1975): 22-37.

Thomas, Joan M., Jon I. Agirre i Ramon A. Mata. Bombs over Biscay, Barcelona and Dresden (1937-1945): From the Spanish Civil War to the Second World War. Tarragona: Publicacions URV, 2019.

Tucker, Robert W. The Law of War and Neutrality at Sea. Washington: United States Government Printing Office, 1957. 
Ward, John. Hitler's Stuka Squadrons: The JU 87 at War 1936-1945. Londyn: Spellmount, 2004.

Wayne, Elliot H. „Open Cities and (Un)defended Places.” The Army Lawyer (1995): 39-51.

Wolfke, Karol. Custom in Present International Law. Wrocław: Zakład Narodowy im. Ossolińskich, 1964.

\section{Inne}

"Commission on the Responsibility of the Authors of the War and on Enforcement of Penalties." The American Journal of International Law 14, (1920): 95-154.

„United Nations War Crimes Commission, Committee III, Request from the Far Eastern and Pacific Sub-Commission concerning the war crime of deliberate bombardment of undefended places, III/77. Legal Tools.” Dostęp październik 27, 2021. https://www.legal-tools.org/doc/ce66b1/pdf/.

„United Nations War Crimes Commission, Deliberate Bombardment of Undefended Places, Draft Report by Committee II, summarizing Documents III/78 and I/82 and embodying the results of the discussion in Committee III meeting of 26th February, 1947 (III/79), Legal Tools." Dostęp październik 27, 2021. https://www.legal -tools.org/doc/b0030f/.

„United Nations War Crimes Commission, Deliberate Bombardment of Undefended Places, Preliminary Report by Egon Schwelb, Legal Officer, III/78, Legal Tools." Dostęp październik 27, 2021. https://www.legal-tools.org/doc/9b9ca9/pdf/.

„United Nations War Crimes Commission, Deliberate Bombardment of Undefended Places, Report by Committee III, C.250, Legal Tools.” Dostęp październik 27, 2021. https://www.legal-tools.org/doc/9b9ca9/.

\section{Internet}

Gustawo, Urena. „Generalfeldmarshall Wolfram Freiherr von Richthofen.” Dostęp wrzesień 21, 2021. https://www.academia.edu/33975006/Generalfeldmarshall_ Wolfram_Freiherr_von_Richthofen.

Peters, Gerhard i John T. Woolley. „An Appeal to Great Britain, France, Italy, Germany, and Poland to Refrain from Air Bombing of Civilians." The American Presidency Project. Dostęp wrzesień 21, 2021. https://www.presidency.ucsb.edu/ node/209957.

Piątkowski, Mateusz. „Bombardowanie Wielunia. Bezsilność prawa międzynarodowego.” Gazeta Prawna.pl, 1 września 2020 roku. Dostęp wrzesień 21, 2021. https://kultura.gazetaprawna.pl/artykuly/1489674,bombardowanie-wielunia-bezsilnosc-prawa -miedzynarodowego.html,komentarze-najstarsze,1.

Piątkowski, Mateusz. „Dr Mateusz Piątkowski: «Bombardowanie Wielunia przypadło na czasy tzw. legalnego bezprawia»" Obserwator międzynarodowy.pl. Dostęp wrzesień 21, 2021. http://obserwatormiedzynarodowy.pl/2019/09/01/dr-mateusz-piatkowski-bombardowanie-wielunia-przypadlo-na-czasy-legalnego-bezprawia -analiza/.

„Two drafts of a letter from Churchill on area bombing, 28 March 1945 and 1 April 1945," National Archives. Dostęp październik 27, 2021. https://www.nationalarchi ves.gov.uk/education/leaders-and controversies/transcript/g1cs3s3t.htm. 
„Wieluń, polska Guernica. Oba miasta zaatakował ten sam zbrodniarz." Deutche Welle. Dostęp wrzesień 21, 2021. https://www.dw.com/pl/wieluń-polska-guernica-obamiasta-zaatakował-ten-sam-zbrodniarz/a-50330625.

\section{STRESZCZENIE}

\section{Mateusz Piątkowski, Bombardowania powietrzne w okresie II wojny światowej w świetle prawa międzynarodowego: problem ataku na Wieluń 1 września 1939 roku}

Lotnictwo wojskowe w okresie Wielkiej Wojny unaoczniło kręgom polityczno-wojskowym wielkie znaczenie sił powietrznych w przyszłych konfliktach zbrojnych. Podkreślano, że statki powietrzne są zdolne do przenoszenia ładunków wybuchowych i mogą razić cele odległe o kilkaset kilometrów od frontu, wprowadzając możliwość atakowania przeciwnika na jego dalekim zapleczu w skali nieznanej w historii wojen. Jednocześnie rozwój lotnictwa wojskowego wywoływał obawy o granice dopuszczalnego zniszczenia i skutecznej ochrony ludności cywilnej przed bombardowaniami powietrznymi. Tworzenie ograniczeń w doborze metod i środków walki jest misją międzynarodowego prawa humanitarnego (do $1949 \mathrm{r}$. nazywanego częściej prawem wojny - ius in bello). Celem niniejszego artykułu jest przedstawienie rozwoju reżimu prawnego odnoszącego się do zjawiska bombardowań powietrznych, począwszy od przepisów uchwalonych podczas konferencji pokojowych w Hadze w 1899 i 1907 r. oraz próby kompleksowego unormowania wojny powietrznej w okresie międzywojennym. Następnie artykuł ocenia adekwatność istniejącej siatki normatywnej względem rzeczywistości pola walki i dramatycznego obrazu bombardowań powietrznych w okresie II wojny światowej, ze szczególnym uwzględnieniem sprawy bombardowania Wielunia 1 września 1939 r.

Słowa kluczowe: Kampania Polska 1939 r., Wieluń, lotnictwo, bombardowanie, prawo międzynarodowe

\section{SUMMARY}

\section{Mateusz Piątkowski, Air bombing during World War II in the Light of International Law: Issues concerning the Attack on Wielun on 1 September 1939}

The use of military aviation during the Great War alerted both political and military circles to the great importance that air power would have in future armed conflicts. It emphasized that aircraft were capable of carrying explosives and could strike targets several hundred kilometers away from the front, which afforded the opportunity to attack the enemy in its distant hinterland on a scale that was hitherto unknown in the history of military conflict. At the same time, the development of military aviation raised concerns about the limits of acceptable destruction and 
the effective protection of civilians from air bombardments. Creating limitations concerning the methods and means of combat was the main mission of international humanitarian law (until 1949 more often called the law of war - ius in bello). The aim of this article is to present the development of legal structures relating to the phenomenon of air bombing, starting with the regulations adopted during the Peace Conferences in The Hague in 1899 and 1907 and the attempts to comprehensively regulate air war in the interwar period. The article also assesses the adequacy of the existing normative network in relation to battlefield reality and the dramatic images of air bombings during World War II, with particular emphasis being placed on the bombing of Wieluń on 1 September 1939.

Keywords: 1939 Polish Campaign, Wielun, aviation, bombardment, international law

\section{АННОТАЦИЯ}

Матеуш Пёнтковски, Бомбардировки с воздуха во время Второй мировой войны в свете международного права: проблема нападения на Велюнь 1 сентября 1939 г.

Военная авиация во время Великой войны заставила политические и военные круги осознать огромное значение военно-воздушных сил в будущих вооруженных конфликтах. В тот период подчеркивалось, что самолеты способны перевозить взрывчатку и могут поражать цели в нескольких сотнях километров от фронта, что дает возможность атаковать противника в его самых отдаленных внутренних районах в масштабах, неизвестных доселе в истории войн. В то же время развитие военной авиации вызвало опасения по поводу пределов допустимого разрушения и эффективной защиты гражданского населения от воздушных бомбардировок. Создание ограничений в выборе методов и средств ведения боя - это задача международного гуманитарного права (до 1949 г. чаще называлось правом войны - ius in bello). Цель данной статьи - представить развитие законодательной базы, относящейся к феномену воздушных бомбардировок (начиная с законов, принятых во время мирных конференций в Гааге в 1899 и 1907 г.) и попыток всестороннего регулирования воздушной войны в межвоенный период. Кроме того, в статье оценивается соответствие существующей нормативной сети с точки зрения действительности поля боя и драматической картины воздушных бомбардировок во время Второй мировой войны, с особым акцентом на бомбардировку Велюня 1 сентября 1939 г.

Ключевые слова: польская кампания 1939 г., Велюнь, авиация, бомбардировки, международное право 